\title{
SIXTH CONGRESSES OF THE MACEDONIAN SOCIETY FOR NEPHROLOGY, DIALYSIS, TRANSPLANTATION AND ARTIFICIAL ORGANS (MSNDTAO) - STIMULUS FOR THE DEVELOPMENT OF NEPHROLOGY IN N. MACEDONIA
}

Momir H. Polenakovic ${ }^{1}$ and Goce Spasovski ${ }^{2}$

\author{
${ }^{1}$ Macedonian Academy of Sciences and Arts Skopje, N. Macedonia \\ ${ }^{2}$ Department of Nephrology, Medical Faculty, University of Ss. Cyril and Methodius, Skopje, N. Macedonia
}

Corresponding author: Momir H. Polenakovic, Macedonian Academy of Sciences and Arts, Blvd. Krste Misirkov 2, Skopje, N. Macedonia, e-mail: momir@manu.edu.mk

\section{ABSTRACT}

The Macedonian Society for Nephrology, Dialysis, Transplantation and Artificial Organs (MSNDTAO) was established on September 1, 1992 in order to stimulate the development of nephrology and to unite experts from all professions interested in the research and treatment of kidney patients. Momir H. Polenakovic was elected President of MSNDTAO.

The First congress of MSNTAO was held in Ohrid from October, 7 to 10, 1993 in hotel "Desaret" under the auspices of the first President of R. Macedonia, Kiro Gligorov. During the Congress, the Balkan Cities Association of Nephrology, Dialysis, Transplantation and Artificial Organs (BANTAO) was formed on October 9, 1993. The idea of cooperation with the Department of Nephrology from the Ege University, Izmir, R. Turkey was promoted. Some of the presented papers were published in the Proceedings "Nephrology '93" as a supplement to the Macedonian medical review. The "Doctrine for performing nephrological activity in the Republic of Macedonia" was also promoted.

The Second congress of MSNDTAO was held in Struga, R. Macedonia from September, 6 to 10, 1997 together with the Second BANTAO Congress. Selected papers were printed in the Macedonian Medical Review.

The Third congress of MSNDTAO was held from May, 30 to June 2, 2001 in Skopje, at the Macedonian Academy of Sciences and Arts (MASA). Proceedings of papers was also published.

In 2011 M. H. Polenakovic was elected Honorary President of MSNDTAO for life, and Goce Spasovski was elected the current President of MSNDTAO.

The Fourth congress of MSNDTAO was held in Ohrid from June, 21 to 24, 2012 together with the Fourth Meeting of the South-Eastern European Pediatric Nephrology Working Group (SEEPNWG).

The Fifth congress of MSNDTAO was held from June, 9 to 12, 2016 in Skopje, at MASA together with the 6th Southeastern European Pediatric Nephrology Working Group (SEPNWG) Meeting and IPNA (International Pediatric Nephrology Association) Teaching Course. The VIII Macedonian-Croatian Nephrology Days were also held during the Congress.

The Sixth congress of MSNDTAO was held from September, 26 to 29, 2019 along with the 15th BANTAO Congress, in Skopje, at MASA. The Congress also marked the 80th anniversary of the birth of M. H. Polenakovic.

Apart from the participants from R. Macedonia, the congress was attended by renowned nephrologists from Europe and the world.

A novelty of the last congresses was the organization of 9 CME (Continuing Medical Education) courses with famous lecturers. CME courses supported by the ERA-EDTA and / or the ISN were as follows: 
2005 - Ohrid (BANTAO), 2006 - Skopje (MSNDTAO), 2009 - Skopje (MSNDTAO), 2010 - Skopje (ERA-EDTA - ESAO), 2011 Skopje (ERA-EDTA - EUTox group), 2012 - Ohrid (MSNDTAO), 2014 Skopje (MSNDTAO), 2016 - Skopje (MSNDTAO), 2018 - Skopje (MSNDTAO - ERA-EDTA \& ISN), 2019 - Skopje (BANTAO - ISN \& ERA-EDTA).

In addition to the congresses, MSNDTAO has held meetings with nephrological associations from the neighboring countries as Croatia, Serbia, Albania and Kosovo.

The congresses of MSNDTAO contributed to the introduction and education of doctors in the diagnosis and treatment of kidney patients. They were a strong stimulus for the development of nephrology in R. Macedonia and beyond.

Keywords: Macedonian Society for Nephrology, Dialysis, Transplantation and Artificial Organs (MSNDTAO), CME (Continuing Medical Education), Congresses

The sections and societies organized by the doctors from different specialties in the medical associations contribute to the education of the health workers and are a support to the education at the clinics of the medical faculties. They are also a place of professional, national and international, contacts between doctors and other experts. The Macedonian Medical Association (MMA) accepts only doctors for its members.

The nephrology section of MMA was established in 1970. The first President was Prof. Dr. D. Hrisoho.

The establishment and work of the Nephrology Clinic at the Medical Faculty of the St. Cyril and Methodius University in 1975 have the most important role in the creation of the nephrological staff in R. Macedonia and beyond in the former Yugoslavia. The Nephrology Clinic was the first institution specialized in the examination and treatment of kidney patients in the former Yugoslavia and in the Balkans.

Nephrologists from R. Macedonia successfully organized the First Scientific Meeting of Nephrologists from Yugoslavia with International Participation, from 26 to 28 September 1977, in Struga, R. Macedonia. It was the most important nephrological meeting, until then, organized by the Society of Nephrologists of Yugoslavia. Proceedings of papers from the meeting were also published [1].
The meeting was a strong stimulus for the development of nephrology in R. Macedonia and in Yugoslavia.

The Macedonian nephrologists successfully organized the Fourth, last, Congress of the Society of Nephrologists of Yugoslavia with international participation, in Skopje, from September, 27 to 30, 1989. The congress was chaired by Prof. Dr. M. H. Polenakovic, the last President of the Society of Nephrologists of Yugoslavia. Proceedings of papers from the Congress were also published [2].

Shortly after the Congress the former Yugoslavia dissolved into bloody military conflicts.

Despite the war and the created hatred and impatience among some people from the former Yugoslavia, the nephrologists wanted to continue the successful cooperation for the benefit of the renal patients.

This desire for cooperation was realized with a proposed initiative for the creation of the Balkan Nephrology Society, given by prof. M. H. Polenakovic, from R. Macedonia, Prof. R. Onen from Turkey, Prof. D. Nenov from R. Bulgaria and Prim. A. Radmilovic from R. Serbia during "Nephrology Today and Tomorrow" - Scientific symposium on the anniversary: 20 years of chronic hemodialysis in Macedonia, 1991, published in the Proceedings of papers from the meeting, in the Macedonian Medical Review [3] and addressed to nephrologists in the Balkans (Fig. 1). 


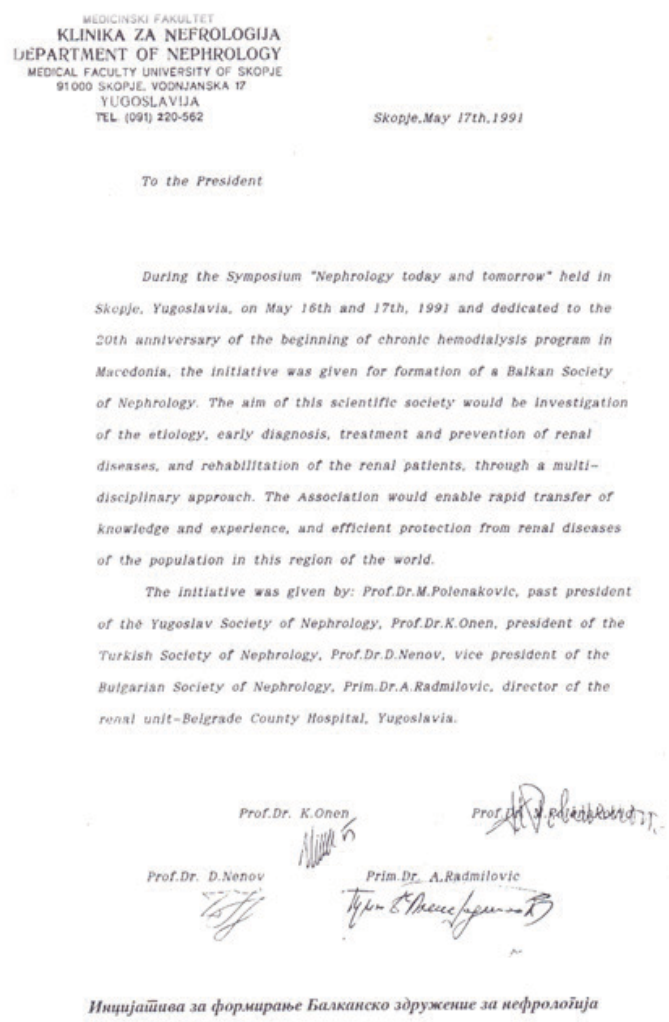

Fig. 1. Initiative for establishing the Balkan Nephrology Society

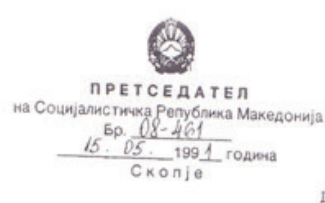

МЕдИцинскИот ФАКУЛТЕТ НА

УНИВЕРЗИТЕТОТ "КИРИЛ И МЕТОДИЈ"

C KO $\mathrm{C} \mathrm{JE}$

Во неможност лично да присуствувам на научниот

симпозиум по повод 20-годишнината на Хроничната хемодијализа во Македонија, Ве молам да ги примите моите исхрени желби за успешна работа,

Крупните научни достигнувана во сферата на оваа

дисциплина на медицинската каука и посебно успетниот развој на здравствените услуги во оваа област се дел на эначајниот разво; на медицинската наука во Македовија, на вејэината поширока меҒународна афирмација и подигањето иа здравствената заштита на населението во Републихата.

Уверен во извонредно значајните кадровски потенцијали и оспособеност на Клинихата за нефрологија, се надевам дека овој Симпозиум ке биде уште едеи творечки поттик за Вашата хумана работа.

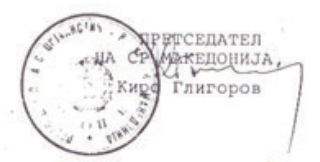
госйоочи Киро Гаиїорое 
The idea for interdisciplinary Balkan Nephrology Association was maturing and we were waiting for its realization.

In order to connect with other professional associations, and for their members to accept other experts such as engineers, biologists, chemists, etc., and not only doctors, the nephrologists from R. Macedonia established the Macedonian Society for Nephrology, Dialysis, Transplantation and Artificial Organs (MSNDTAO) on September 1, 1992, in Skopje, ant its statute allowed the admission of members and experts from other professions, not just doctors. An interdisciplinary approach improves the examina- tion and treatment of kidney patients. Prof. Momir H. Polenakovic was elected President of the Association.

\section{FIRST CONGRESS OF MSNDTAO}

After a year of work, the First Congress of MSNDTAO was organized in Ohrid, R. Macedonia, on October, 7 to 10, 1993, at the "Desaret" Hotel.

We had the great honor - the first President of R. Macedonia, Kiro Gligorov to be the patron of the Congress.

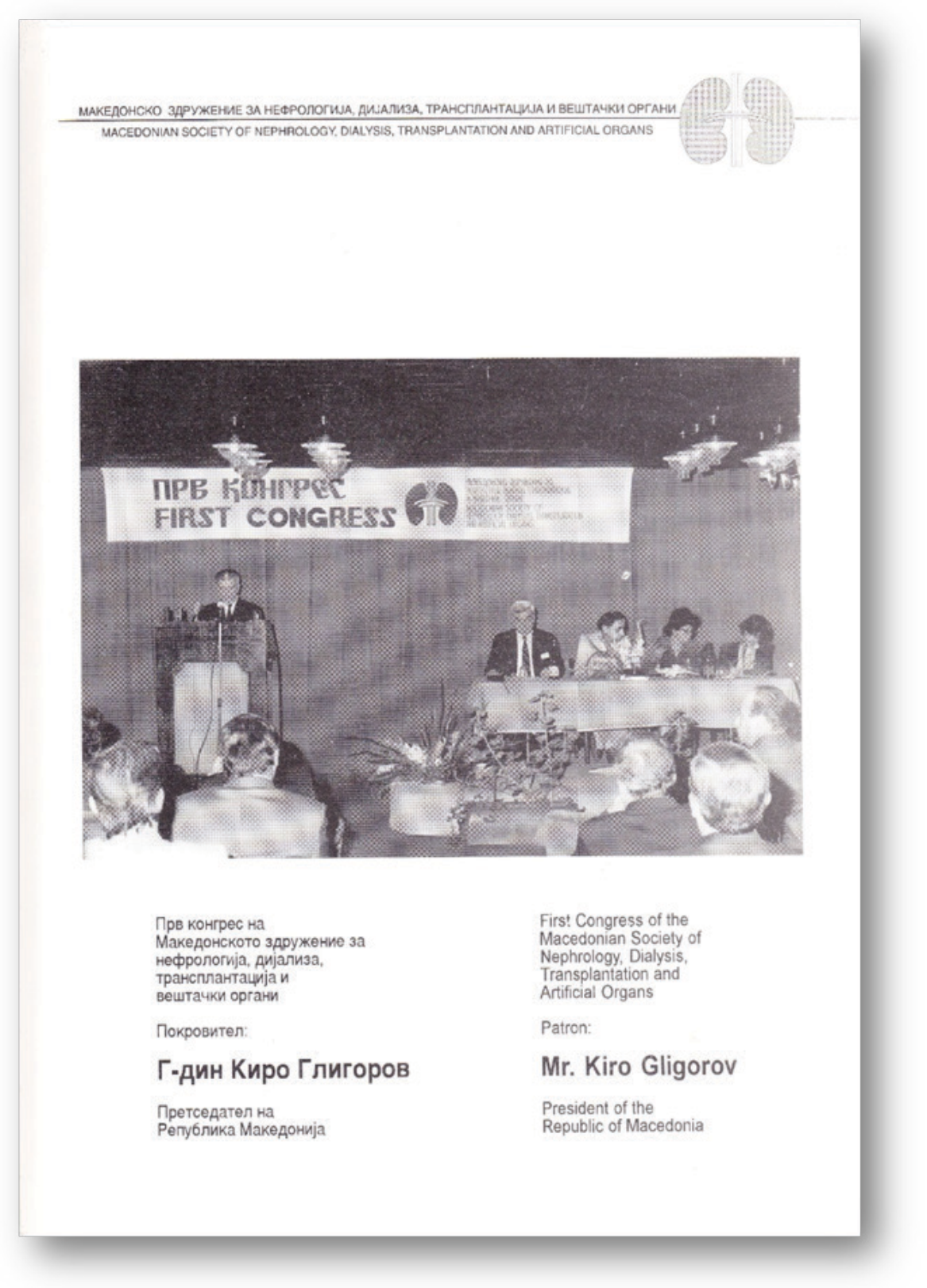

Fig. 3. President Kiro Gligorov at the First Congress of MSNDTAO in Ohrid 
In the welcoming speech, the patron of the Congress, the President of R. Macedonia, Kiro Gligorov stressed the importance of such international scientific meetings for the development of science and the inclusion of R. Macedonia in the European and world scientific trends. He pointed out that the participation of numerous well-known nephrologists from Europe and the United States shows the high affirmation of our nephrology in the world, and a kind of recognition for the

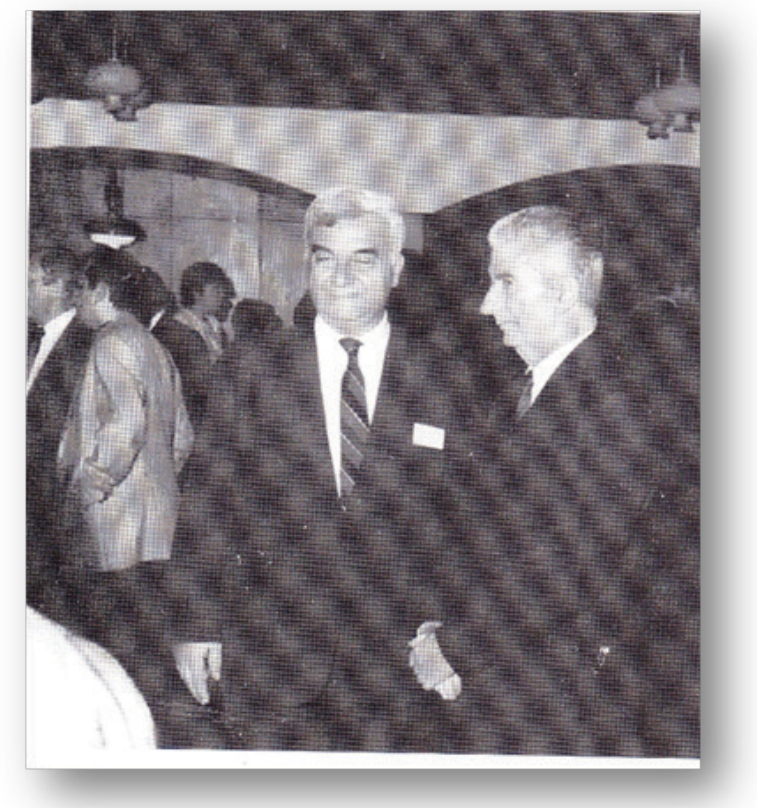

Fig. 4. From left to right: Momir Polenakovic and President Kiro Gligorov at the First Congress medical and other staff dealing with this issue, as well as for the achievements in the treatment and rehabilitation of kidney patients in R. Macedonia.

Acad. P. Davchev promoted the Proceedings of papers from the scientific symposium "Nephrology Today and Tomorrow", held at the Macedonian Academy of Sciences and Arts on May, 16 to 17, 1991, on the occasion of 20 years of chronic hemodialysis in R. Macedonia [3].

Acad. Davchev said that the Proceedings enclosed papers from renowned nephrologists from the country and Europe, and reflected the continuous progress of nephrology in R. Macedonia for 20 years.

He emphasized and read the welcome letter from President K. Gligorov to the participants at the symposium.

During the work of the First Congress of MSNDTAO, on October 9, 1993 in Ohrid, the Balkan Cities Association of Nephrology, Dialysis, Transplantation and Artificial Organs (BANTAO) was established [4].

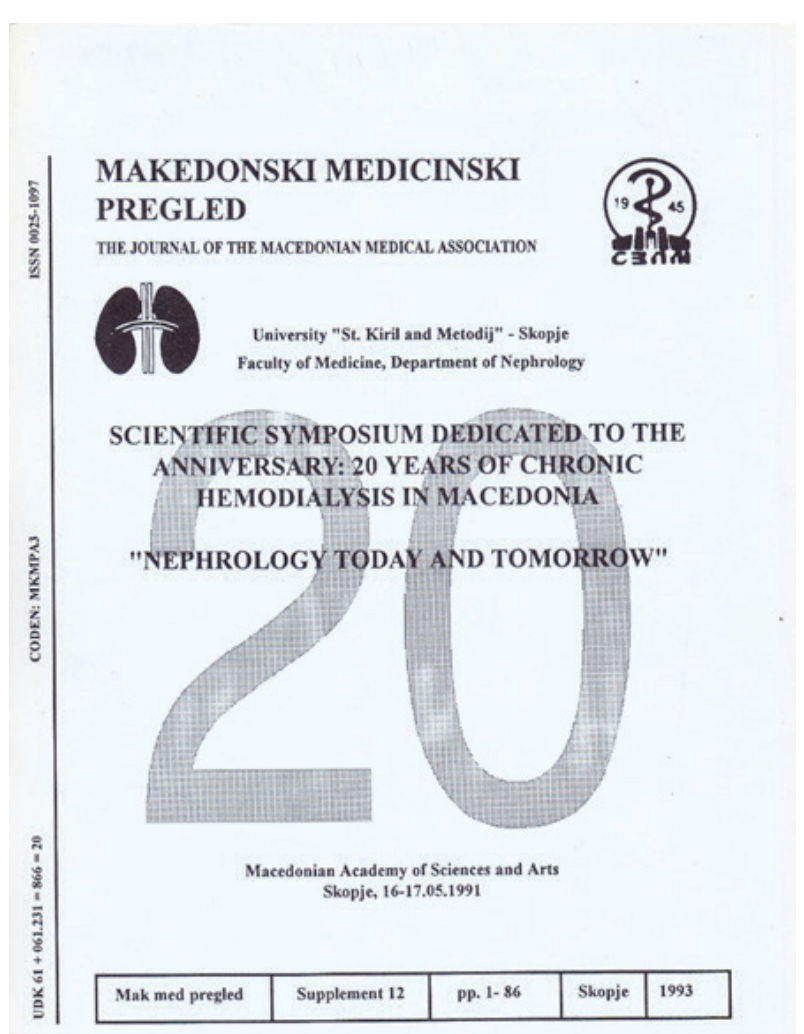




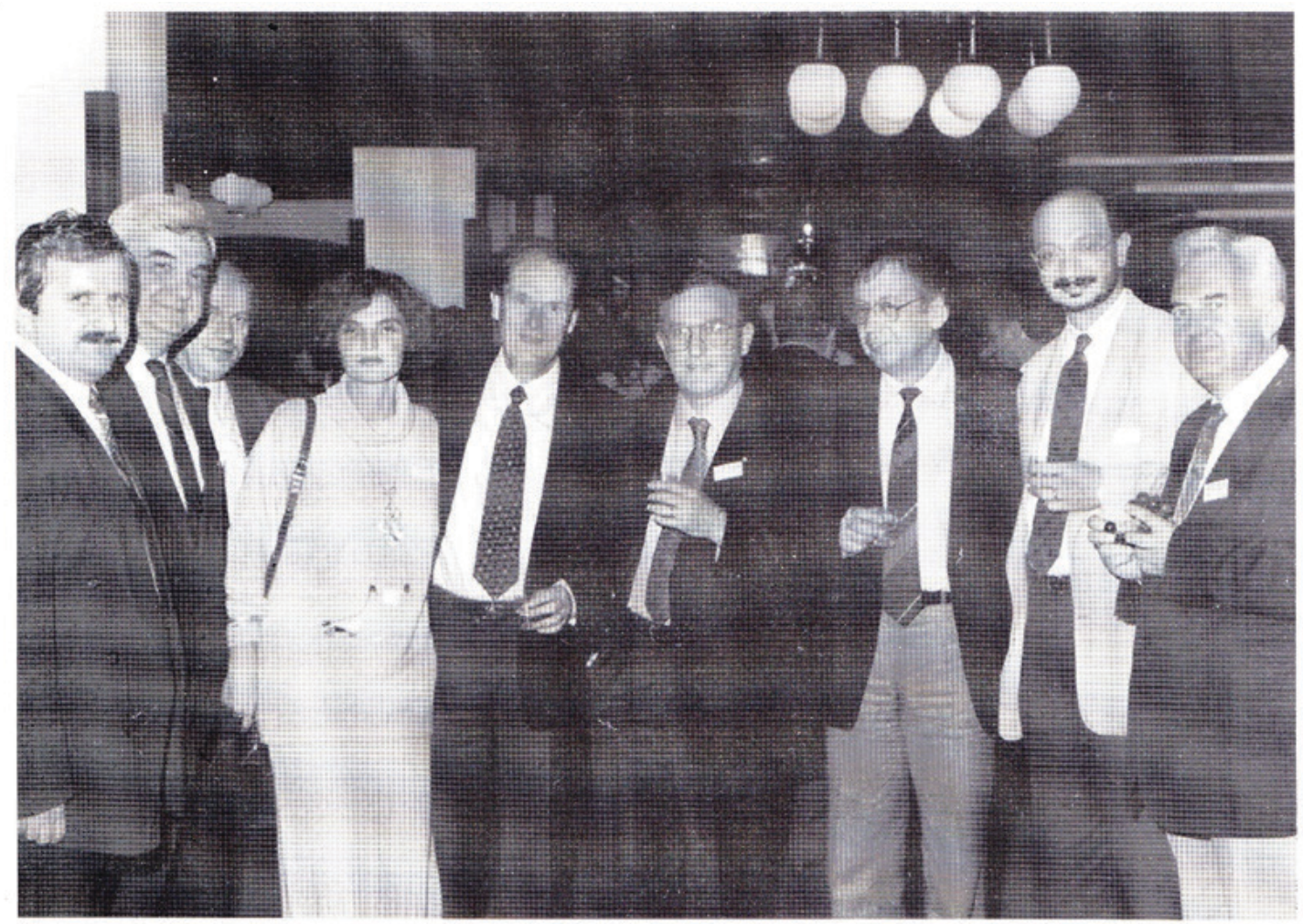

Дел од учесниците на Конгресот: (од лево кон десно)

Инг. Ј. Србиноски - Југохром, Тетово

Проф. др. М. Поленаковиќ - Клиника за нефрологија, Скопје

Инг. Т. Мукаетов - Алкалоид, Скопје

Дипл. економ. Л. Софревска - Алкалоид, Скопје

Проф. др. H. Klinkmann - Росток, Гермманија

Проф. др. P. Zuccheli - Болоња, Италија '

Проф. др. V. Siniukhin - Москва, Русија

Проф. др. S. Mujais - Чикаго, САД

Проф. дp. D. Nenov - Варна, Бугарија

Fig. 6. From left to right: J. Srbinoivski, M. Polenakovic, T. Mukaetov, L. Sofrevska, H. Klinkmann, P. Zuccheli, V. Siniukhin, S. Mujais, D. Nenov

The idea of cooperation with the Clinic of Nephrology from the EGE University, Izmir, R. Turkey was promoted, for which a cooperation agreement was later signed.
Some of the presented papers were published in the Proceedings of papers "Nephrology '93" as a supplement to the Mac. Med. Review [5]. 
izMIR, DECEMBER 2, 1993

\title{
AGREEMENT
}

\begin{abstract}
BETWEEN THE NEPHROLOGICAL DEPARTMENTS OF THE MEDICAL FACULTIES OF THE UNIVERSITY "ST. CYRIL AND METHODIUS" OF SKOPJE, MACEDONIA AND EGE UNIVERSITY, IZMIR, TURKEY.
\end{abstract}

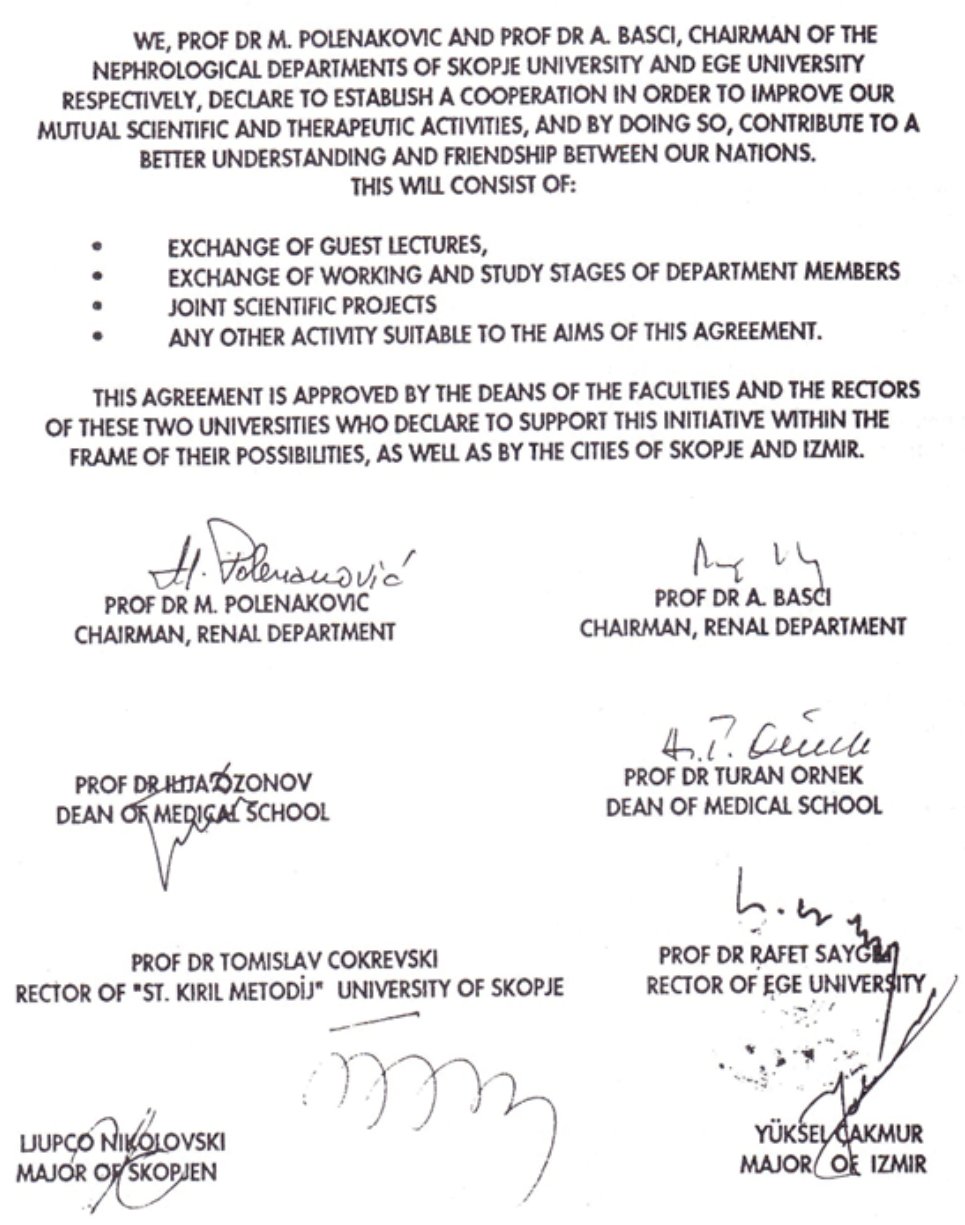

Соработка на Клиниката за нефрологија со ЕГЕ Универзитетот од Измир, Турција

Fig. 7. Agreement with the EGE University from Izmir, Turkey 

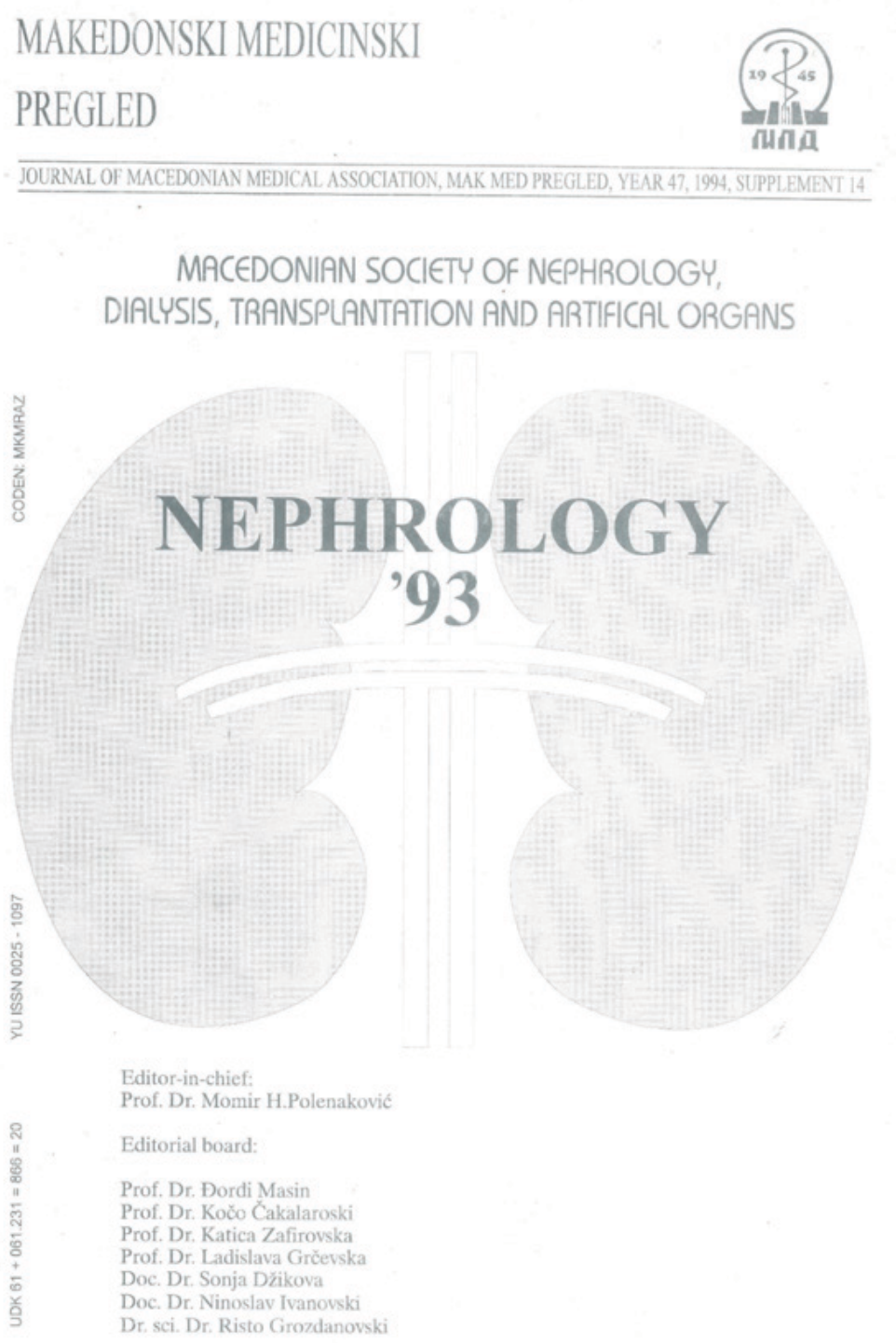

Fig. 8. Nephrology '93

Renowned nephrologists from R. Macedonia and abroad in their papers presented the latest knowledge on the topics: 1. Epidemiology of renal disease in R. Macedonia and 2. Acute and chronic renal failure; as well as through round tables on 1. Anemia and renal insufficiency and 2. Uroinfections.

Let us mention some of the participants in the Congress:

H. Klinkmann (Germany), P. Zucchelli (Italy), B. Hartley (UK), E. J. D. Mees (Holland, Turkey), S. Kodra (Albania), S. Strahinjic, V. Petronic, Lj. Djukanovic, V. Nesic, D. Velimirovic, V. Savic, V. Djordjevic, Lj. Velickovic, V. Stefanovic, A. Radmilovic (Serbia), D. Falkenha- gen (Austria), H. Brynger (Sweden), S. K. Mujais (USA), L. A. van Es (Holland), D. Nenov, V. Ikonomov, B. Deliyska, Z. Kirjakov (Bulgaria), F. Kokot, A. Wiecek (Poland), V. Sinuikhin, E. Stetsyuk (Russia), F. P. Schena (Italy), M. E. de Broe (Belgium), L. Truong (USA), F. Akcicek (Turkey), D. Pavlovic, S. Cala, N. Jankovic (Croatia).

Nephrology '93 encloses 83 papers presented at the Congress.

During the Congress Prof. J. Tofoski, Minister of Health in the Government of R. Macedonia promoted the "Doctrine for performing nephrological activity in the Republic of Macedonia". The doctrine was prepared by: Gj. Masin, M. Polenakovic, K. Zafirovska, K. Chakalaroski, S. Dziko- 
va, N. Ivanovski, L. Grchevska, R. Grozdanovski and A. Onchevski, all employees of the Clinic for Nephrology at the Medical Faculty of the Skopje University of "St. Cyril and Methodius".

This first doctrine for performing nephrological activity in $\mathrm{R}$. Macedonia requires care for nephrology patients based on world accepted and known principles for rational and efficient diagnosis and therapy.

In this Doctrine, a division of tasks was performed between the primary, secondary and tertiary nephrological protection.

The First Congress of MSNDTAO in independent and sovereign R. Macedonia in 1993 confirmed the successful development of nephrology in our country. Our weaknesses and dissatisfactions that should be removed in the examination and treatment of kidney patients were also presented.

\section{SECOND CONGRESS OF MSNDTAO}

The Second Congress of MSNDTAO was in conjunction with the Second BANTAO Congress, held on September, 6 to 10, 1997 in Struga, R. Macedonia.
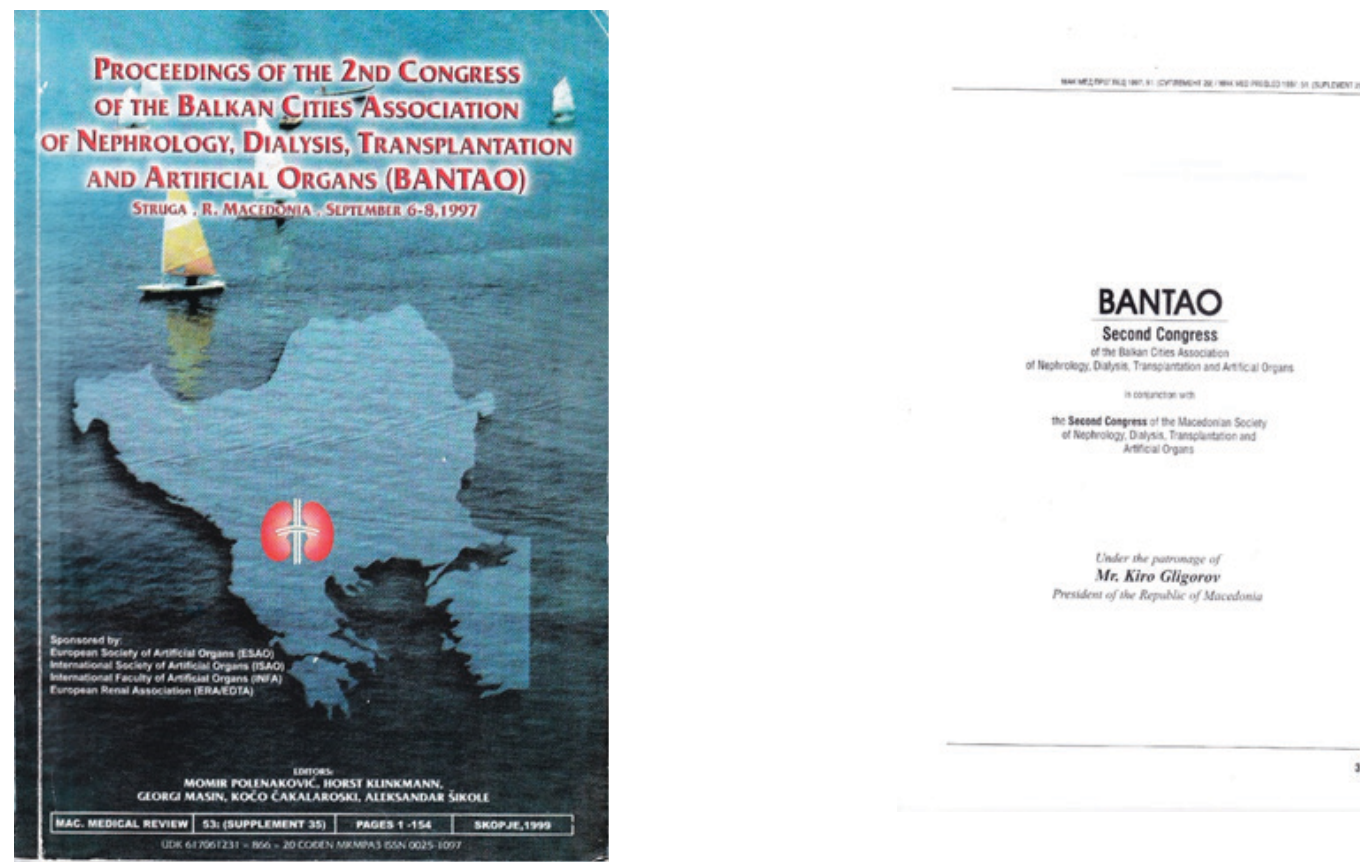

Fig. 9. Second Congress of MSNDTAO and of BANTAO

The congresses were sponsored by: European Society for Artificial Organs (ESAO), International Society for Artificial Organs (ISAO), International Faculty for Artificial Organs (IFAO) and the Euro- pean Renal Association - European Dialysis and Transplantation Association (ERA-EDTA).

The congresses were under the auspices of the President of R. Macedonia, Kiro Gligorov. 

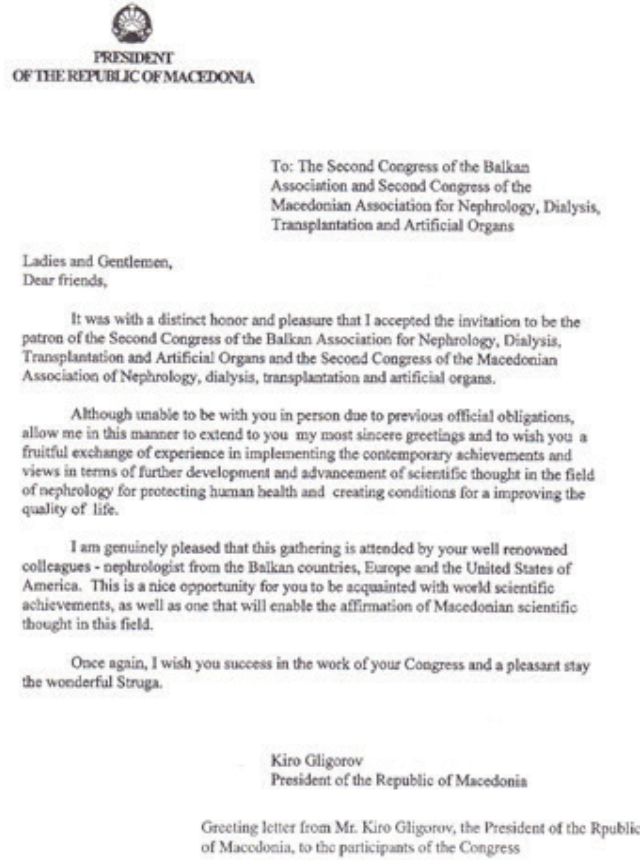

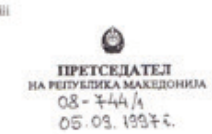

до

ВТОРИОТ КОНТРЕС НА БАЛКАНСКАТ АСОЦИЈАЦИА И ВТОРИОТ КОНГРЕС TPAHСТUИАНТАНИА И ВЕLITАЧКИ OPTAHI

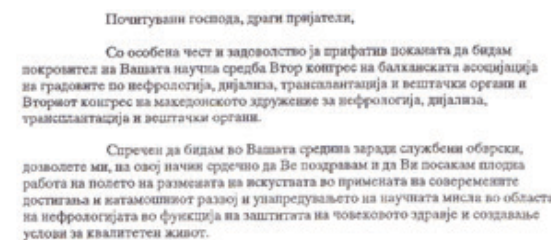

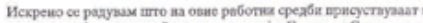

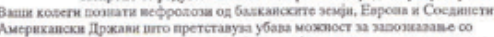

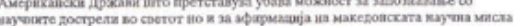

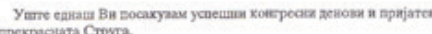

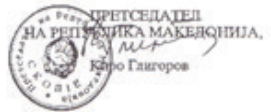

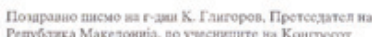

Fig. 10. Welcome address by K. Gligorov to the participants of the Second Congress of MSNDTAO and of BANTAO

Selected papers presented at the congresses ings - BANTAO in Mac. Med. Review; 53; 1999, were published in proceedings of papers as a supple- Supplement 35, pp. 1-154 [6]. ment to the Macedonian Medical Review: Proceed-

Welcome to Struga, to the Second Congress of the Macedonian Society of Nephrology: Dialysis. Transplantation and Artificial Organs. September 8th to 10th. 1997,

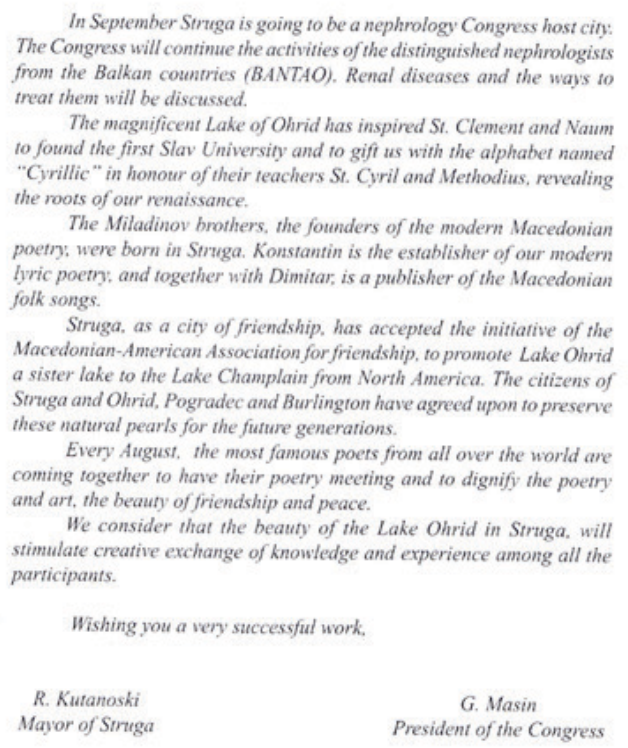

Fig. 11. Welcome address by the Mayor of Struga, R. Kutanoski and the President of the Congress, G. Masin 

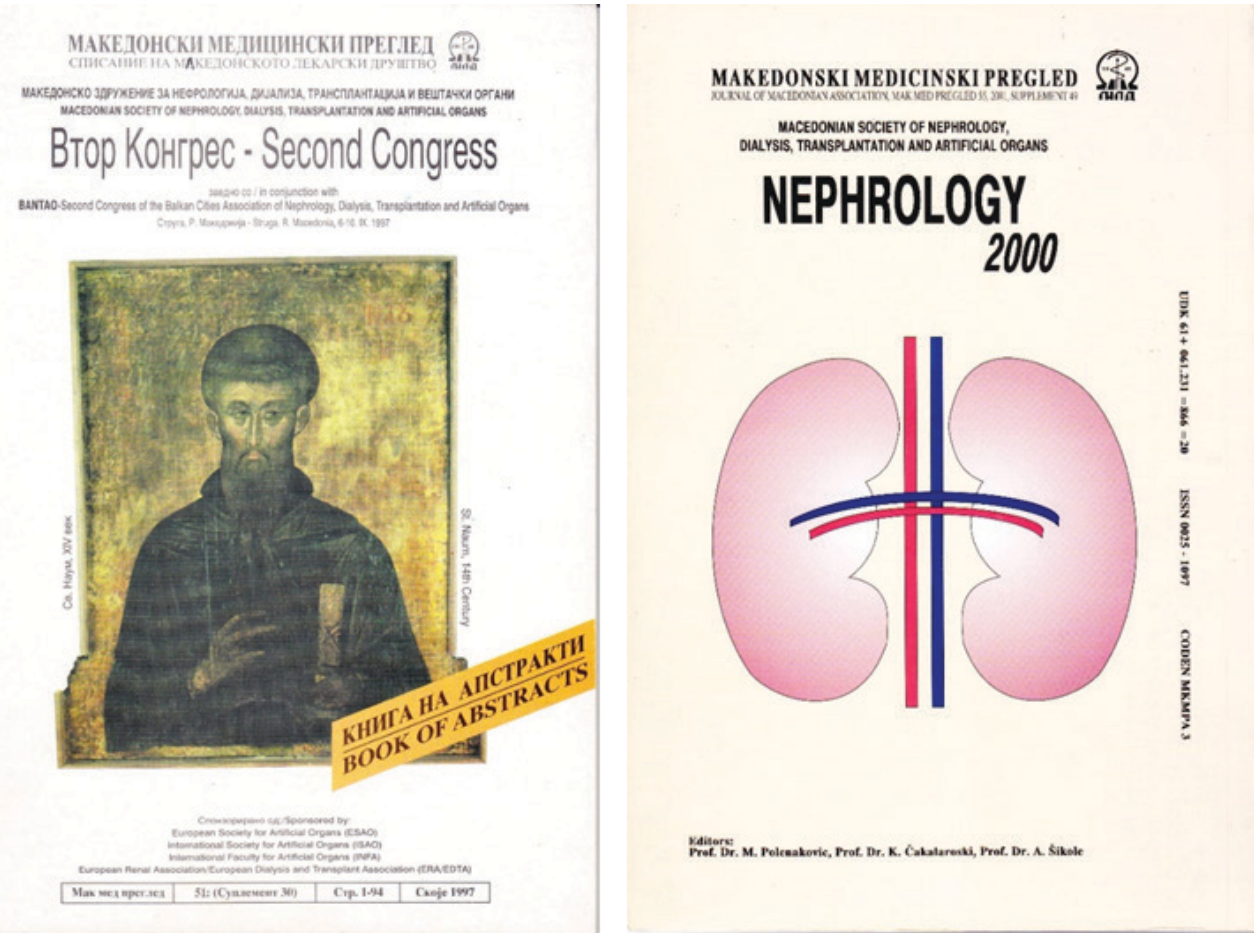

Fig. 12. Book of Abstracts and Nephrology 2000

The proceedings comprise papers presented at the congresses, by domestic authors from R. Macedonia and by foreign authors.

We mention some of the foreign authors by sessions. In the session on the epidemiology of renal diseases the papers of the following foreign authors have been published: M. E. De Broe, Belgium; Lj. Djukanovic, Serbia; M. Barbullushi, Albania and E. Hasanoglu, Turkey. In the sessions on primary and secondary glomerulopathies, systemic diseases and renal involvement the papers of the following authors have been published: J. S. Cameron, UK; C. M. Lockwood, UK; F. P. Schena, Italy; F. Kokot, Poland; B. Delyska, D. Monova, A. Rapondjieva, Bulgaria. In the session on acute and chronic renal failure (renal replacement therapy, dialysis and renal transplantation) the papers of the following authors have been published: A. K. Mandal, USA; O. S. Better, Israel; B. Rippe, Sweden; A. M. Borissova, E. Vazelov, G. Mihailov, Bulgaria; T. Caja, Albania; G. Schulman, USA; S. K. Tuglular, Turkey; R. Vanholder, Belgium; B. Pecovnik-Balon, Slovenia; D. B. Jovanovic, Serbia.

In the session for pediatric nephropathy the paper of A. Peco-Antic, Serbia has been published.

The papers of the following authors have been published in the session Drugs and the Kidney: E. J. Dorhout Mees, Turkey; D. Nenov and E. T. Andreev, Bulgaria.
The papers of the following authors have been published in the session on Balkan Nephropathy: S. Susa, S. Strahinjic, D. Bukvic, V. Momcilovic, Serbia.

In Nephrology 2000 have also been published the nephrological doctrines on: proteinuria and nephrotic syndrome; approach to diagnostics in the treatment of urinary infections; approach to the diagnosis and therapy of hypertensive emergencies and critical conditions; approach to the diagnosis and therapy of renal osteodystrophy; erythropoietin in the treatment of renal anemia; parameters for evaluation and adequate iron supplementation during erythropoietin therapy; resistance to erythropoietin therapy (EPO) - mechanisms and European recommendations for the treatment of anemia in patients with chronic renal failure.

The Second Congress of MSNDTAO was a further development of nephrology in R. Macedonia.

\section{THIRD CONGRESS OF MSNDTAO}

The third congress of MSNDTAO was held from May, 30 to June 2, 2001, in Skopje, R. Macedonia, at the Macedonian Academy of Sciences and Arts, under the auspices of Acad. Gjorgji Efremov, President of MASA. 


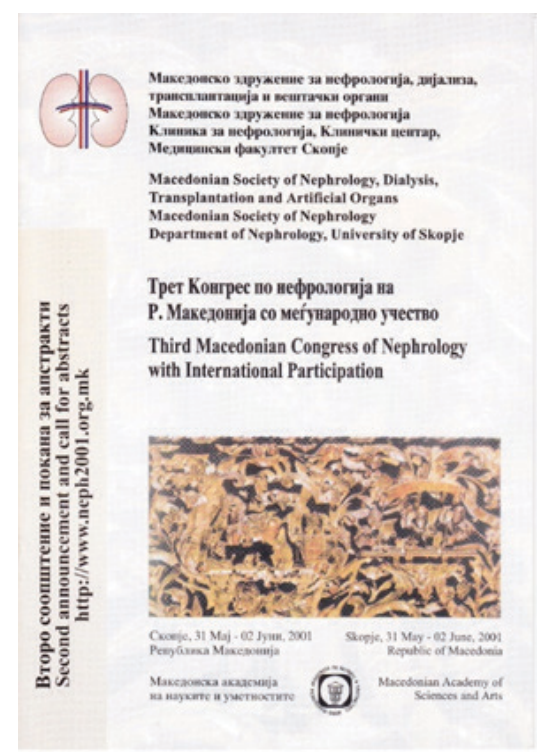

Fig. 13. Announcement of the Third Congress of MSNDTAO

In the welcome address to the participants of the Congress, the organizers partially mentioned the successes of the nephrologists from R. Macedonia in the past period. We give the part of the address:

"Over the past three decades nephrology in Macedonia has continuously progressed introducing the achievements of the modern medicine. Several methods of diagnosis and treatment of renal disease were standardized. The renal biopsy with immune histological and electron microscopic evaluation was first introduced in 1969. Ultrasonography with interventional diagnostic methods was introduced in 1984. Chronic hemodialysis program was established in 1971, followed by the development of other blood purification procedures (hemoperfusion, CAVH, plasmapheresis, etc.). Today, the number of treated patients per million population exceeds 500, with a well-developed dialysis infrastructure throughout the country. Erythropoietin therapy was first introduced in 1989. Vascular access for chronic hemodialysis was created in 1976. The first bone biopsy was performed in 1984. The kidney transplantation from a living donor was performed in 1977. The CAPD program was initiated in 1988. The hypertension unit was established in 1984."

We mention the sessions of the Congress that cover the current problems in nephrology:

Epidemiology, prevention and progression of chronic renal disease; urinary tract infection; intensive care in nephrology - acute renal failure; renal parenchymal disease; diagnostic methods in nephrology; renal replacement therapy; drug and the kidney; kidney transplantation; pediatric nephrology and hypertension.

The participants in the Congress from $\mathrm{R}$. Macedonia presented numerous papers, but also the participants from abroad attracted attention by sharing their experiences. Let us mention some of the participants from abroad: D. Ferluga (Slovenia) gave a pre-congress lecture: Heterogeneity of histopathology and pathogenesis of Lupus nephritits (LN) - clinical significance of biopsy evaluation. There have been presentations by: M. E. De Broe, Belgium; M. R. Daha, Netherlands; V. Stefanovic, J. Dimitrijevic, S. Samardzic, A. Gligic, Dj. Maksic, R. Bogdanovic, S. Baljosevic, Yugoslavia; P. Toon, UK; Z. A. Massy, France; A. Vizjak, A. Bren, S. Kaplan-Pavlovic, Slovenia; D. Nenov, V. Nenov, S. Staykova, Bulgaria, V. R. Kovacic, Belgium; Ali Basci, Turkey; A. Wiecek, Poland; G. Coen, Italy; J. Gogusev, France. Some of these authors published their presentations in the Proceedings of the Third Congress (8). The exchange of experiences improved the diagnosis and treatment of kidney patients.

144 abstracts were printed in the Book of Abstracts [7], and 56 papers in the Proceedings of the Third Congress of MSNDTAO. 

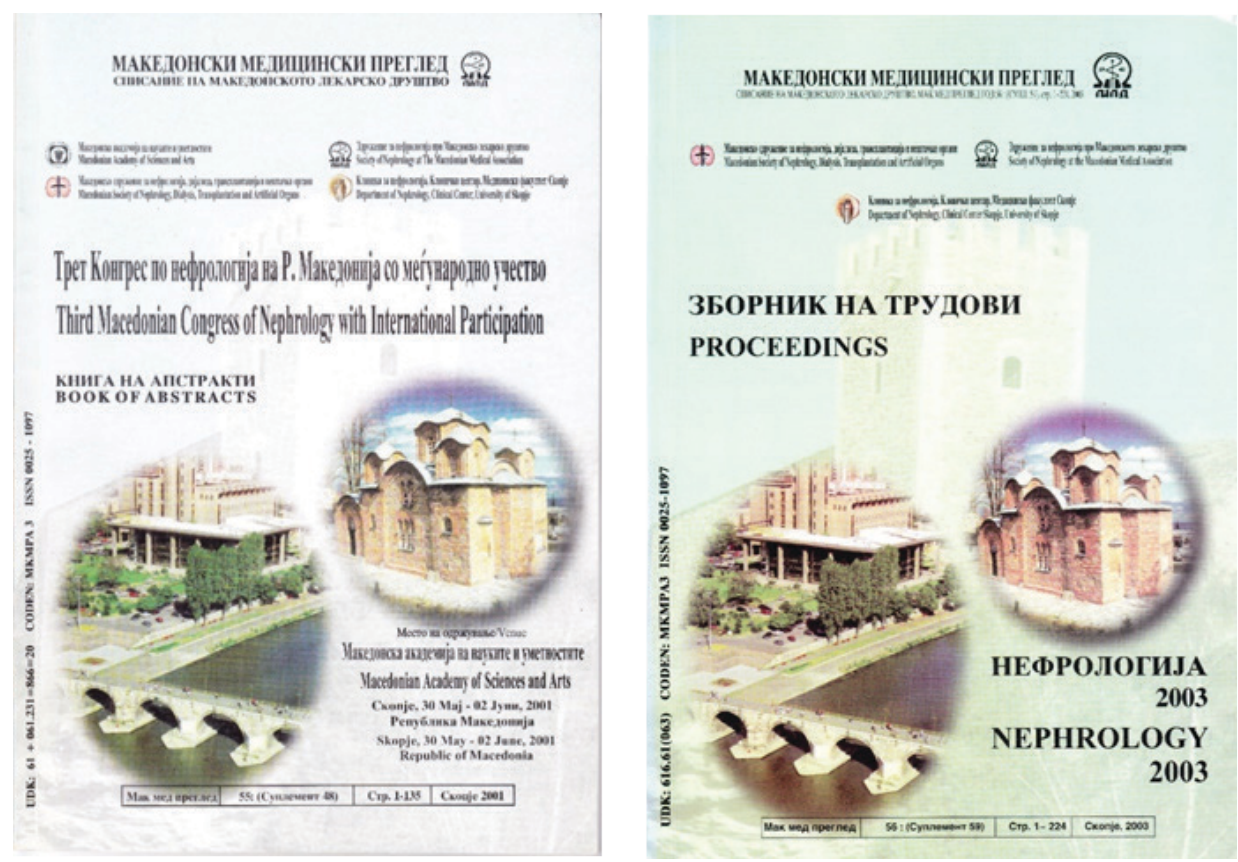

Fig. 14. Book of Abstracts and Proceedings of the Third Congress of MSNDTAO

In 2005 a BANTAO congress was held in Ohrid and the first EDTA-CME course in R. Macedonia and in the Balkans, organized by MSNDTAO.

At the annual assembly of MSNDTAO in 2011 Goce Spasovski was elected the current President of MSNDTAO, and M. Polenakovic was elected honorary President of MSNDTAO for life.

Goce Spasovski is the only member from the Balkan countries elected to the ERA-EDTA Council in two terms, 2006-2009 and 2016-2019, and was the head of the ERA-EDTA Education Committee in the period 2009-2014.

Fig. 15. Program of the Fourth Congress

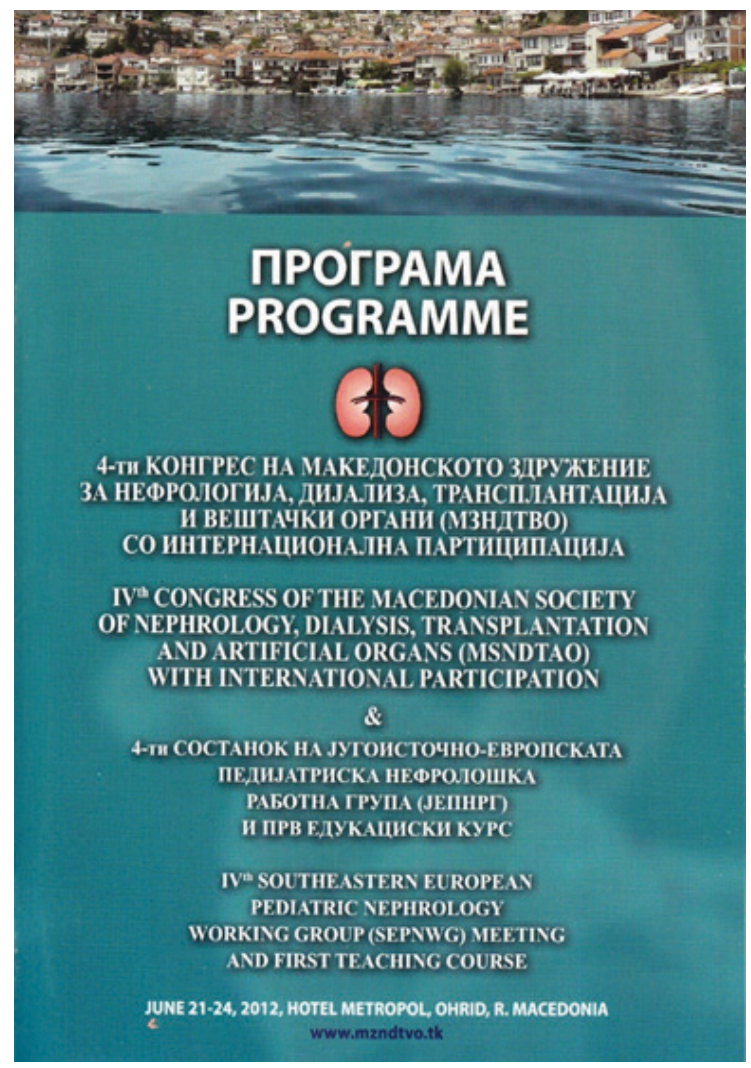



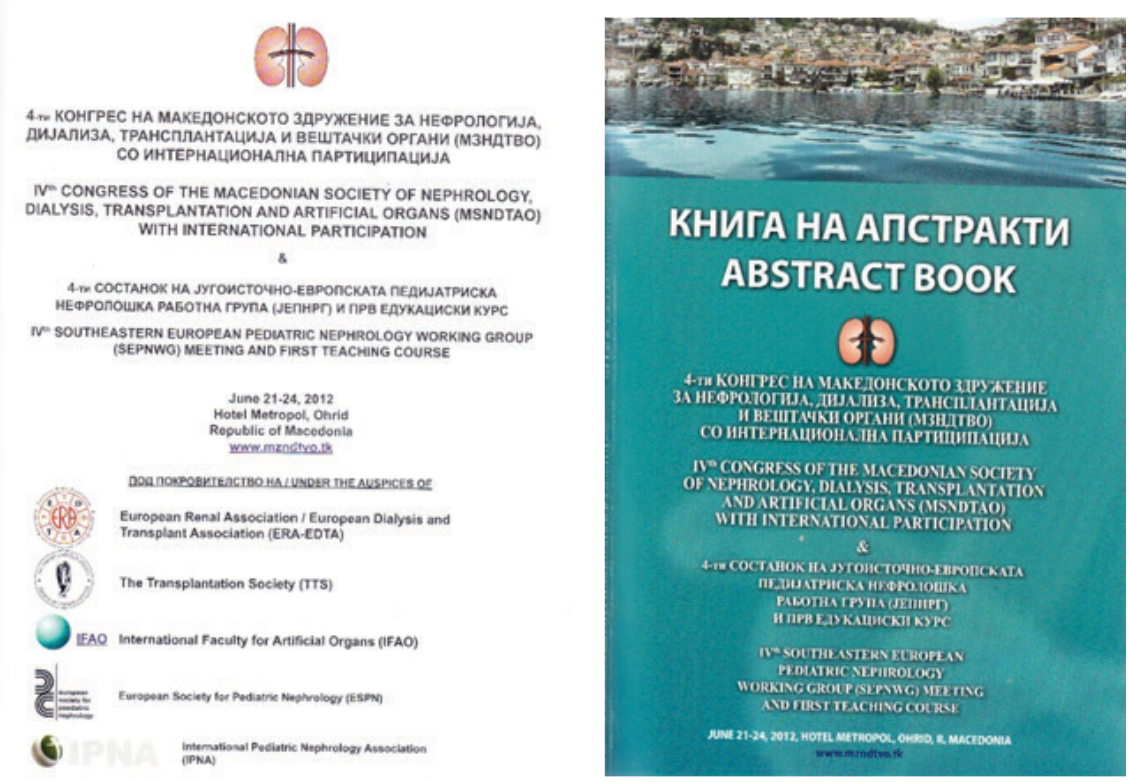

Fig. 16. Book of Abstracts of the Fourth Congress

The Macedonian Society of Nephrology, Dialysis, Transplantation and Artificial Organs (MSNDTVO) held its Fourth Congress with international participation from June, 21 to 24, 2012, in Ohrid, Republic of Macedonia. The European Renal Association - European Dialysis and Transplantation Association (ERA-EDTA) was a patron of this congress with support in the form of a one-day course for Continuing Medical Education (CME) and with a number of topics presented from members of the group for development of recommendations (European Renal Best Practice - ERBP group). For the first time at this Congress, and in general in the region, support and auspices were received from the International Transplantation Society (TTS), in the context of the main theme of the Congress - the development of renal transplantation not only in the Republic of Macedonia but also in the Balkans. Also, as a parallel event, a 1.5 day workshop was held on "Technical requirements for organ and tissue donation and transplantation" with support from the Technical Assistance and Information Exchange body of the European Council - TAIEX, which organizationally and scientifically supports candidate countries in their educational projects and, within the South Eastern Europe Health Network, co-operation through the regional health development centre for transplantation and organ donation from the Republic of Croatia.

Other sponsors were: the International Faculty for Artificial Organs - IFAO, the European
Society for Paediatric Nephrology - ESPN and the International Paediatric Nephrology Association - IPNA.

A distinguishing feature of the Congress was that, for the first time in the Balkans, it was a joint meeting with pediatric nephrologists, i.e. the Fourth Meeting of the South-Eastern European Pediatric Nephrology Working Group (SEEPNWG) and the first educational course supported by the European and the International Pediatric Nephrology Association.

On the first two days, the congress and the workshop were attended by 342 delegates from 21 countries. There were 32 invited lectures from the EU and USA presented by such eminent nephrologists as President and Secretary of the ERA-EDTA Prof. Raymond Vanholder and Prof. Andrzej Wiecek, as well as the President of the International Transplantation Society, Prof. Francis Delmonico. There were also fruitful discussions over the 36 regional leaders' lectures in their respective areas of nephrology in the Balkans and Turkey, as well as 24 accepted topics for oral presentation and 50 poster presentations.

The work on the third day of the Congress was completely devoted to renal transplantation from both a living donor and a cadaver through a full day CME Course entitled "Improving organ donation and transplantation as current medical practice." Much interesting data was learnt about the organization of this activity as a complex mul- 
tidisciplinary project from the experience of other countries, successfully organized on this issue. In addition, there were conclusions and proposals of modifications for the further progress in the development of transplantation in the Balkans and other developing countries.

The Congress was rated by all delegates and lecturers to be on a high scientific level and well organized. Of particular importance is also the fact that, after many years, all presidents of the national nephrology associations and nephrologists from the Balkans and beyond were gathered together, which enabled an exchange of experience and achievements, but also the possibility of considering an actual dimension of the achieved level of implementation of particular guidelines in the respective countries, as a special incentive for further development where it is really needed.

The Fourth Congress of MSNDTAO was successful in scientific terms, but also showed the good-will for regional cooperation and friendship for the generations of nephrologists from the wider Balkan region, showing that despite political turbulences, nephrologists remain doctors without borders and prejudices [8].

\section{THIRD CONGRESS OF MSNDTAO}

The 5th Congress of MSNDTAO with international participation was held on June, 9 - 12, 2016 in the Macedonian Academy of Sciences and Arts (MASA) together with the 6th Southeastern European Pediatric Nephrology Working Group (SEPNWG) Meeting and IPNA Teaching Course. The VIII Macedonian - Croatian Nephrology days were also held on June 9, 2016 in MASA.

The organizers of the Congress: Goce Spasovski, Olivera Stojcheva Taneva, Momir Polenakovic and Velibor Tasic sent a message to the participants, as follows:

"MSNDTAO since its creation in 1992 has a history of 4 National Congresses and this year we'll have our anniversary of the fifth Congress. In addition, many section and international meetings with nephrologists from the neighboring and countries from former YU exchanging knowledge and updating the current information of specific topics have been held over the years. Throughout the Society we support the World Kidney Day and Donor Day initiatives and promote publicly and professionally improvement in kidney trans- plantation program as well as other types of renal replacement therapy. Our society is also an initiator of the BANTAO Society creation and we do hope to host for third time BANTAO Congress in Macedonia in 2019."

During the Congress opening ceremony, Goce Spasovski (Macedonia) talked about "MSNDTAO - activities over the years and awarding the supporters"; Raymond Vanholder (Belgium) - "Burden of CKD (Chronic kidney disease) and replacement therapy"; Andrzej Wiecek (Poland) - "Perspectives of the treatment in patients with CKD"; Momir Polenakovic (Macedonia) - "Horst Klinkmann - scientist, visionary and friend" and the Blaze Koneski medal, the highest recognition of the Macedonian Academy of Sciences and Arts was awarded to Horst Klinkmann; Horst Klinkmann (Germany) - "Blood Purification and its Input on the development of Nephrology".

The ERA-EDTA and ISN CME course titled "Diagnosis and treatment of CKD - a new evidence and guidelines" was held.

The following presentations were delivered in the session "Renal replacement therapy and complications": Raymond Vanholder (Belgium) - "Management of the uremic syndrome"; Francesco Locateli (Italy) - "New drugs for anemia treatment in CKD: the narrow street between innovation and concerns" Goce Spasovski (Macedonia) - "Cinacalcet treatment in CKD stage 5D patients - is it justified"; Petar Kes (Croatia) - "Acute Kidney Injury After Cardiac Surgery: Prevention and Treatment"; Dimitris Goumenos (Greece) - "Hemodialysis or peritoneal dialysis for renal replacement therapy in patients with heart failure?"

The following presentations were delivered in the "Transplantation" session: Umberto Maggiore (Italy) - "Strategies to increase donor pool and access to kidney transplantation"; Soren Schwartz Sorensen (Denmark) - "ABOi renal transplantation - present status and lessons learned"; Jadranka Buturovic Ponikvar (Slovenia) - "Preemptive kidney transplantation"; Umberto Maggiore (Italy) - "Long term risk of living donation: a critical appraisal of the current evidence"; Soren Schwartz Sorensen (Denmark) - "Use of alloreactivity measures in risk prediction for renal transplant course. How far are we from personalized medicine?"

The following presentations were delivered in the "Treatment and complications in CKD" 
session: Rafael Ponikvar (Slovenia) - "Vascular access surgery performed by nephrologist"; Petar Dejanov (Macedonia) - "Forty years of experience in vascular accesses creation in R. Macedonia"; Halima Resic (Bosnia and Herzegovina) - "Challenges in RRT in Bosnia and Herzegovina in the last 15 years"; Nada Dimkovic (Serbia) "Achievement of guidelines targets: PD vs. HD"; Merita Rroji (Albania) - "The role of Peritoneal Dialysis in current Renal Replacement Therapy"; Gjulsen Selim (Macedonia) - "Magnesium and cardiovascular mortality in hemodialysis patients".

The following presentations were delivered in the "Pre- and post - transplantation diagnosis and management" session: Pablo Cannata-Ortiz (Spain) - "Renal Biopsy: Difficult clinico-pathological diagnosis"; Mehmet Sukru Sever (Turkey) - "Body size and outcomes in dialysis and transplant patients - Does it matter?; Sanjin Racki (Croatia) - "HD or PD before kidney transplantation"; Jelka Masin Spasovska (Macedonia) "Mechanisms and consequences of arterial hypertension after renal transplantation"; Burak Kocak (Turkey) - "Complications after live donor nephrectomy - possible consequences?".

In the "Meet the expert" session Soren Schwartz Sorensen and Umberto Maggiore talked about Transplantation.

The following presentations were delivered in the "Clinical nephrology" session: Alketa Koroshi (Albania) - "Kidney Disease in Multiple Myeloma"; Sanja Simic Ogrizovic (Serbia) - "Renal biopsy in the elderly"; Olivera Stojceva-Taneva (Macedonia) - "How reliable are different equations for estimating kidney function in CKD pts?"; Evgueniy Vazelov (Bulgaria) - "Vitamine status in CKD patients"; Myftar Barbullushi (Albania) - "Hyponatremia perceived from a clinician perspective"; Enisa Mesic (Bosnia and Herzegovina) - "The fate of the acute and chronic kidney patients during the wars and natural disasters".

The following presentations were delivered in the "Clinical nephrology and guidelines implementation" session: Andrzej Wiecek (Poland) - "Management of diabetic and CKD stage 3b or higher (eGFR $<45 \mathrm{~mL} / \mathrm{min}$ ) patients"; Ivan Rychlik (Czech Republic) - "Non-diabetic renal disease among diabetic patients undergoing renal biopsy"; G. Saadi (Egypt) - Mesenchymal
Stem Cell therapy in nephrology practice; Goce Spasovski (Macedonia) - "Implementation of the guidelines in low and middle income countries"; Wim Van Biesen (Belgium) - "What is known and what we do in medicine - Guidelines implementation".

The following presentations were delivered in the "Long-term immunosuppression - benefits and harms" session: John Boletis (Greece) - "Rituximab in ANCA - associated vasculitis"; Smaragdi Marinaki (Greece) - "Pregnancy in SLE"; Ladislava Grcevska (Macedonia) - "Membranous nephropathy".

The following presentations were delivered in the "Hypertension - treatment of choice" session: Adalbert Schiller (Romania) - "ACEI and ARB. Is there a dark side of the moon?"; Ingrid Prkacin (Croatia) - "Renal denervation".

The following presentations were delivered in the "Hypertension - treatment of choice" session: Wim Van Biesen (Belgium) - "Palliative care, Dialysis modality choice or withdrawal"; Raymond Vanholder (Belgium) - "Cost of RRT - the difference between developed and low and middle income countries"; Hari Polenakovik (USA) - "New Treatments for HCV in CKD Patients"; Nikolina Basic Jukic (Croatia) - "Renal transplantation in long-term dialysis patients"; Alberto Ortiz (Spain) - "Mortality in chronic kidney failure"; Meet the expert session: Raymond Vanholder and Angel Argiles - "RRT and complication treatment"; Soren Schwartz Sorensen and Andrzej Wiecek - "Guidelines".

The following presentations were delivered in the "Omics in CKD" session: Harald Mischak (Germany) - "Urinary peptides for diagnosis and prognosis of CKD"; Antonia Vlahou (Greece) "Investigating the urine proteome as a source of CKD biomarkers and predicting therapeutic targets; techniques and examples of applications"; Angel Argiles (France) - "Transcriptomics and Metabolomics in CKD"; Aikaterini Papagianni (Greece) - "FGF-23: an emerging cardiovascular risk marker in chronic kidney disease"; Katerina Markoska (Macedonia) - "Urinary proteomic-based classifier for identification of CKD patients with improvement in eGFR"; Martin Pejchinovski (Macedonia) - "Urine proteome analysis of ADPKD patients selected by a TKV imaging classification method". 


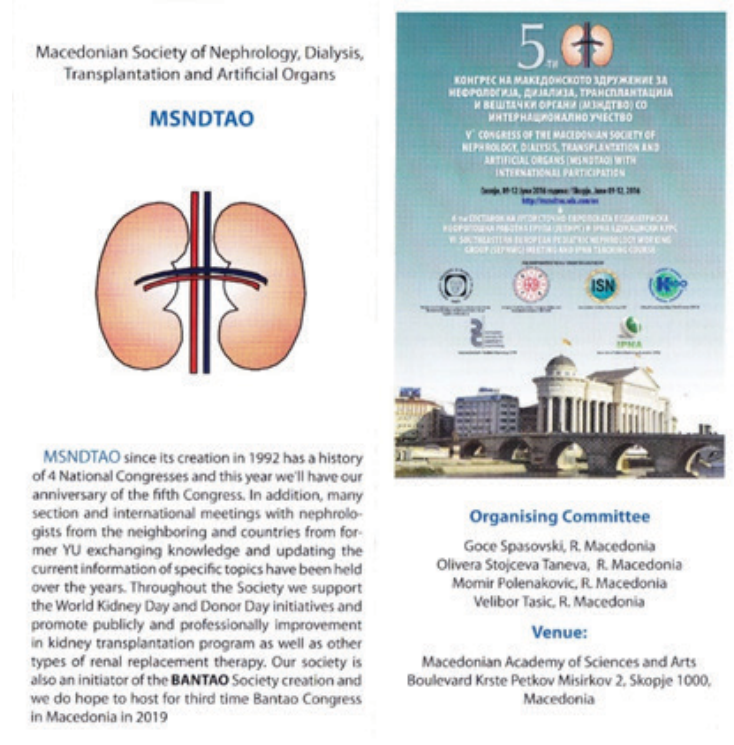

Fig. 17. Part of the history of MSNDTAO

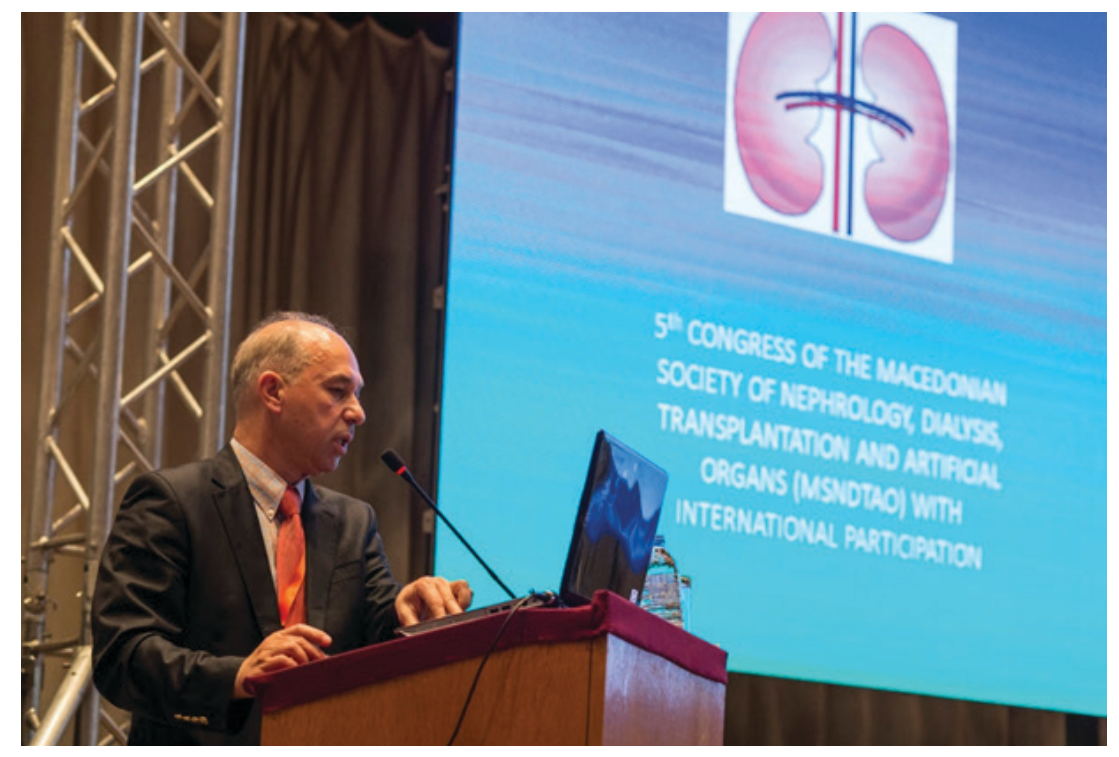

Fig. 18. Opening of the Congress Goce Spasovski

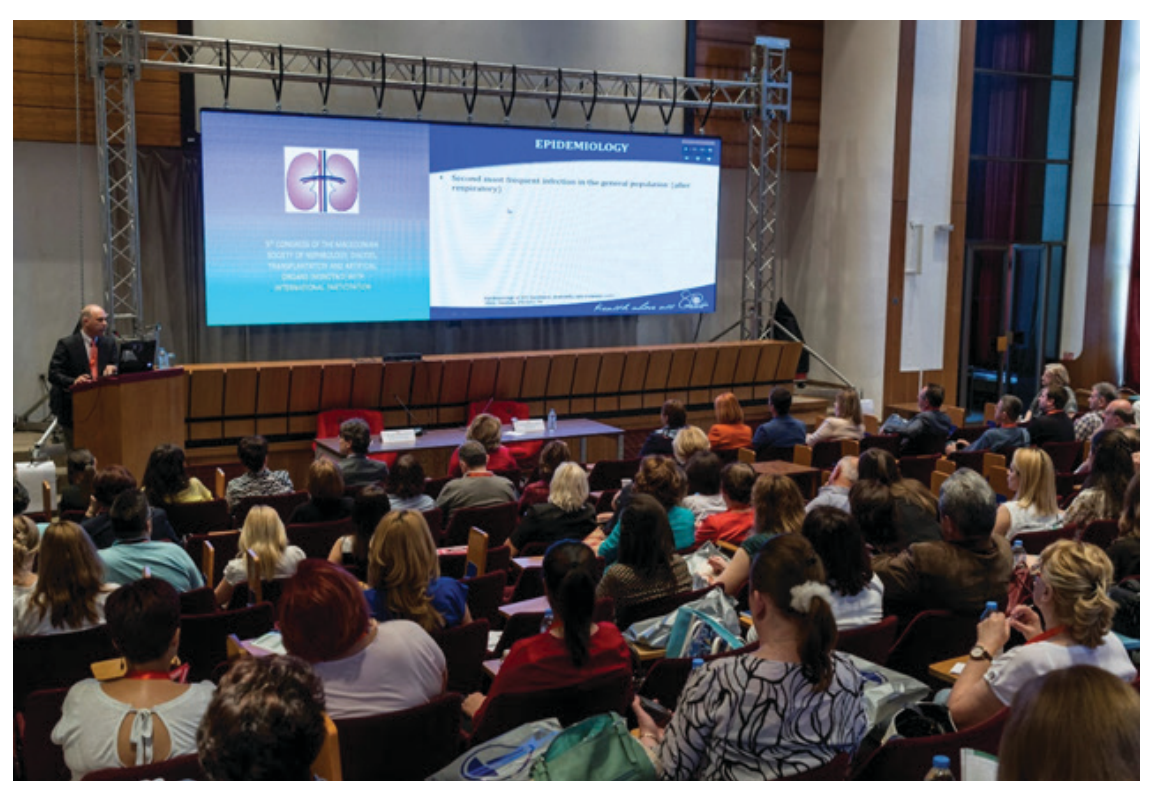

Fig. 19. Opening of the Congress 

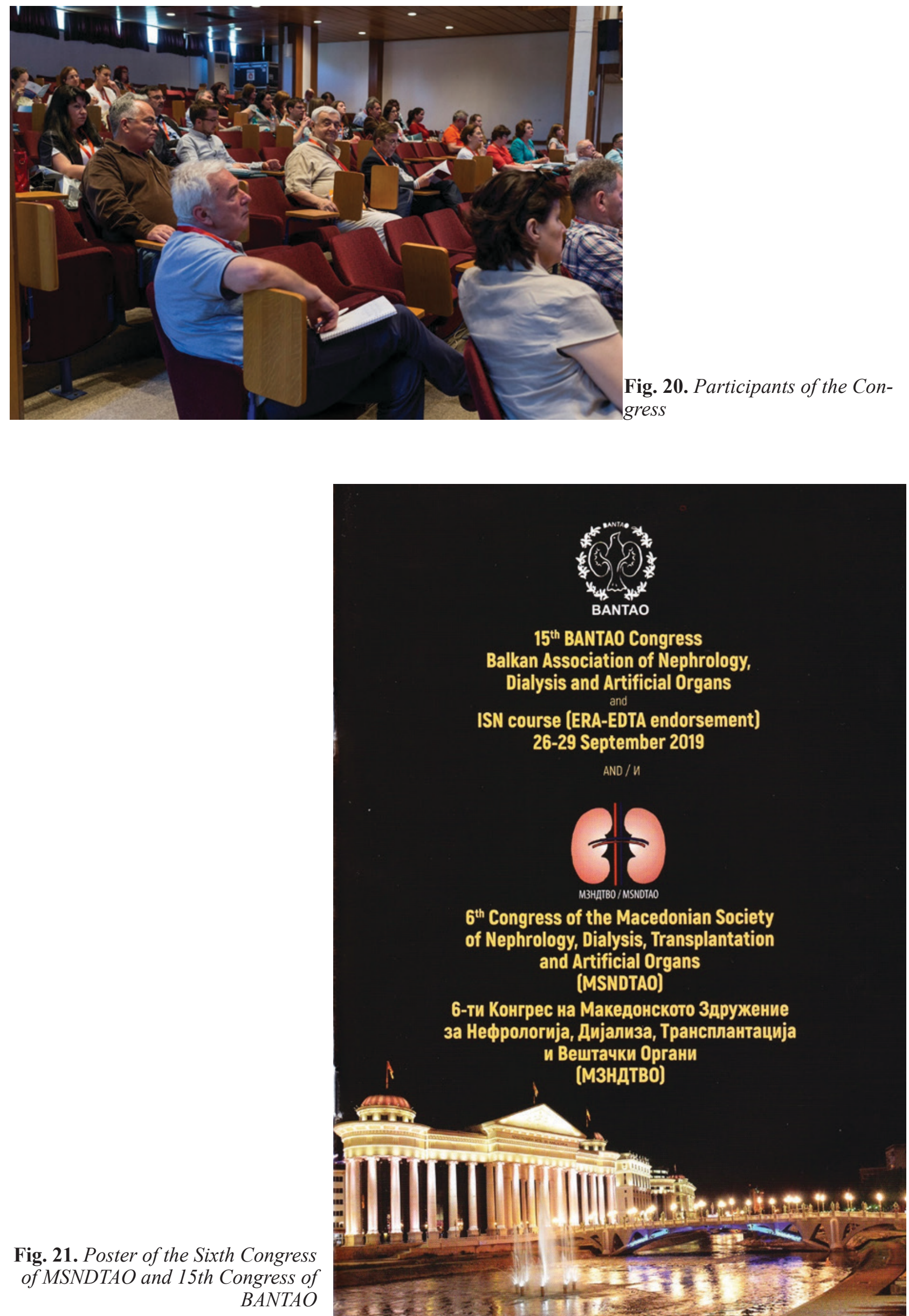

Fig. 21. Poster of the Sixth Congress of MSNDTAO and 15th Congress of BANTAO 


$$
\begin{aligned}
& \text { In fionor of the 80th amniversary of } \\
& \text { Academician Momir Polenakovic }
\end{aligned}
$$

$15^{\text {th }}$ BANTAO Congress

Balkan Association of Nephrology,

Dialysis and Artificial Organs

BANTAO

and

ISN course [ERA-EDTA endorsement]

26-29 September 2019

AND / $\mathrm{n}$

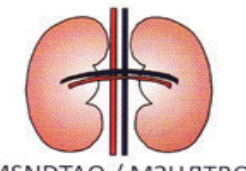

MSNDTAO / МЗНДТВО

$6^{\text {th }}$ Congress of the Macedonian Society of Nephrology, Dialysis, Transplantation and Artificial Organs

(MSNDTAO)

6-ти Конгрес на Македонското Здружение за Нефрологија, Дијализа, Трансплантација и Вештачки Органи

(Мзндтво)
September 26-29, 2019 / 26-29 Септември 2019 година

Skopje, Republic of North Macedonia

https://mzndtvo.wixsite.com/bantao2019en
Fig. 21. Program of the Sixth Congress of MSNDTAO and 15th Congress of BANTAO

Fig. 22. Opening of the Sixth Congress of MSNDTAO and of 15 th BANTAO Congress

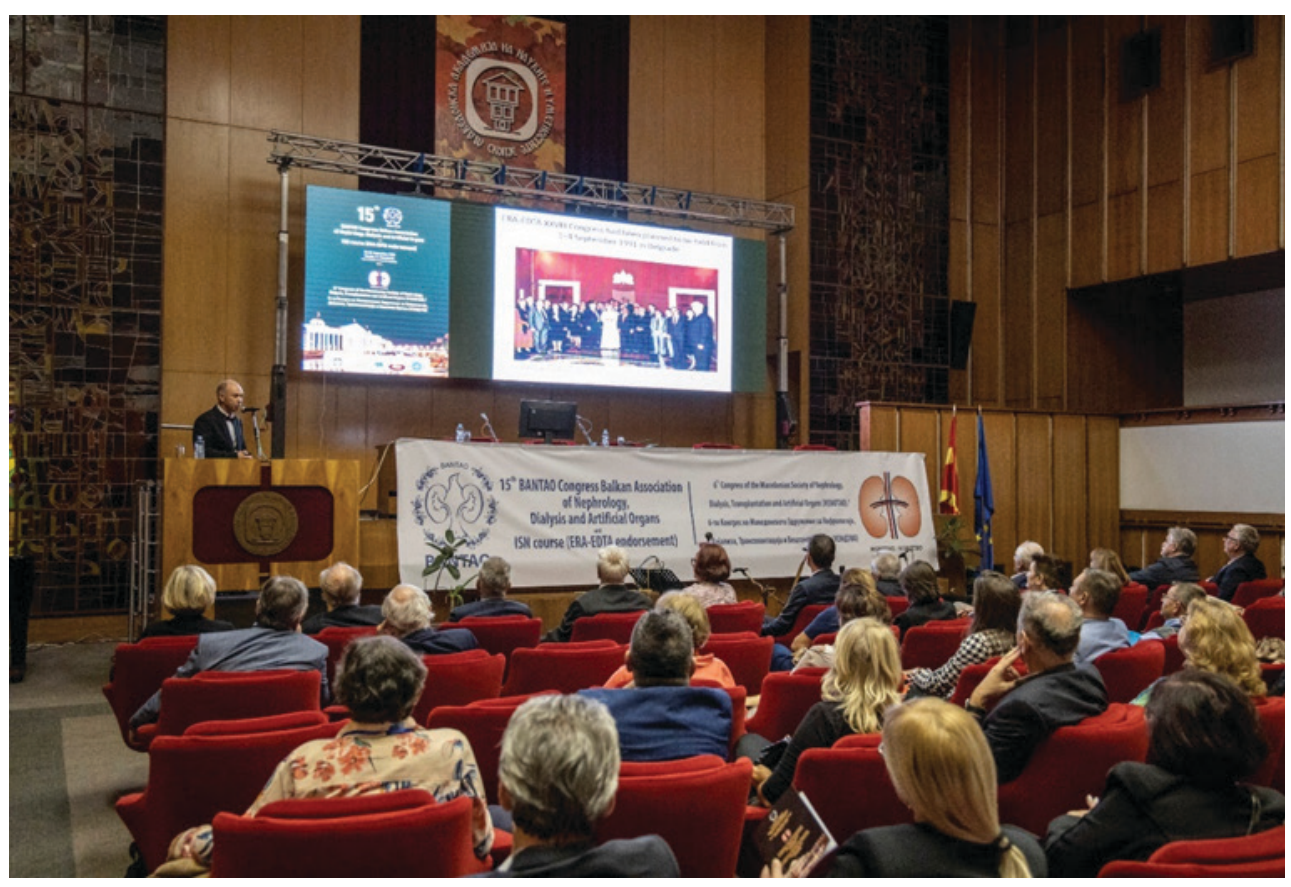


In the period from 26th until 29th of September 2019, the 15th BANTAO Congress (Balkan Cities Association of Nephrology, Dialysis, Transplantation and Artificial Organs) in conjunction with the 6th Congress of the Macedonian Society of Nephrology, Dialysis, Transplantation and Artificial Organs (MSNDTAO) was held in Skopje, Republic of North Macedonia. The Congress was hosted by the Macedonian Academy of Sciences and Arts (MASA), which premises were very appropriate for the scientific level of the whole event. Alongside, there was the South Eastern European Pediatric Nephrology Working
Group (SEPNWG) scientific session as part of the whole event, emphasizing the challenges that our youngest patients are facing and presenting new treatment options for this most vulnerable population. [9]

The Balkan Association of Nephrology, Dialysis, Transplantation and Artificial Organs (BANTAO) was established in Ohrid, Republic of Macedonia, on 9th October 1993, as the only professional association of this kind in the Balkans and Southern Europe. The main goal of the BANTAO was to promote scientific and technical cooperation for renal diseases and artificial

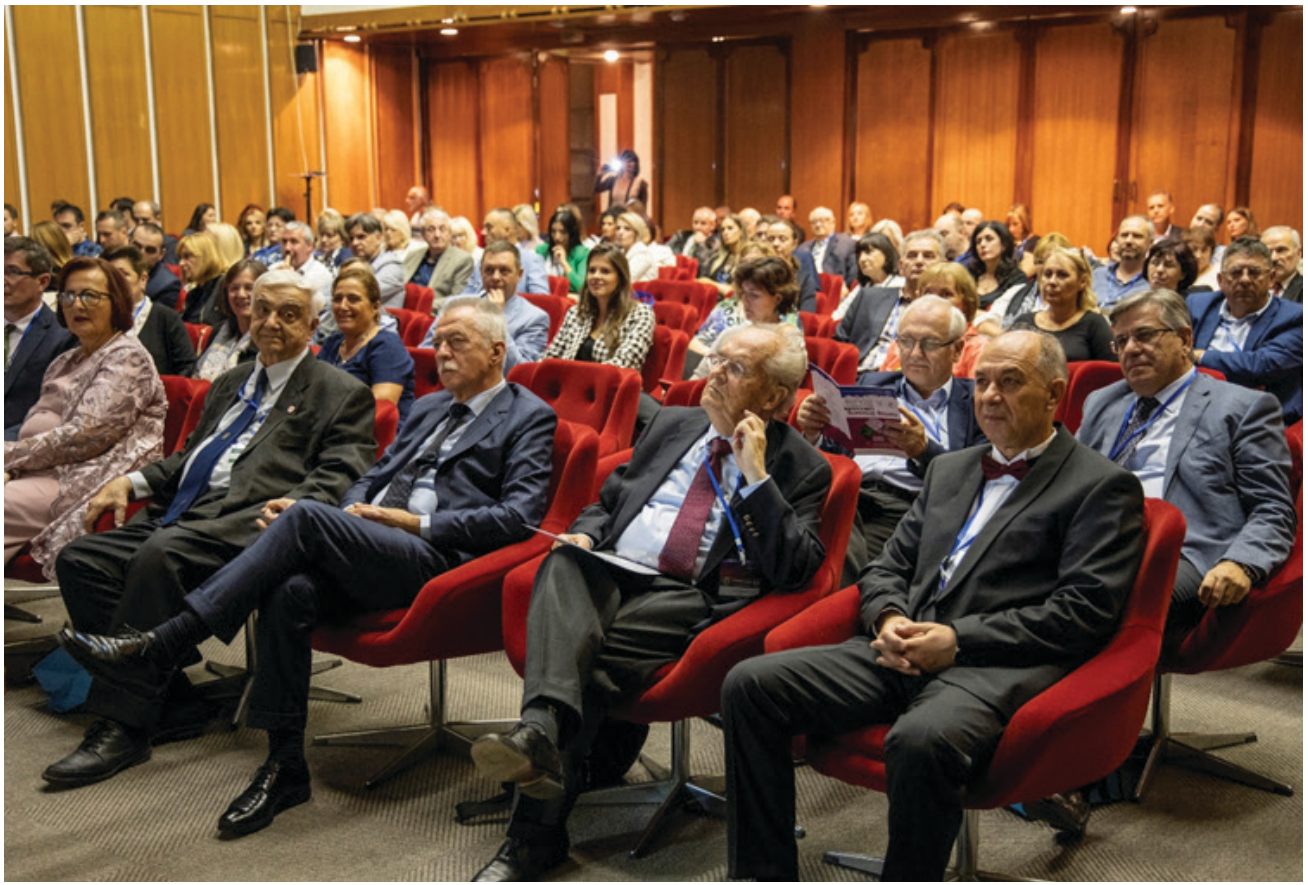

Fig. 23. Participants at the Congress

Fig. 24. Olivera Stojcheva Taneva, Secretary of MSNDTAO

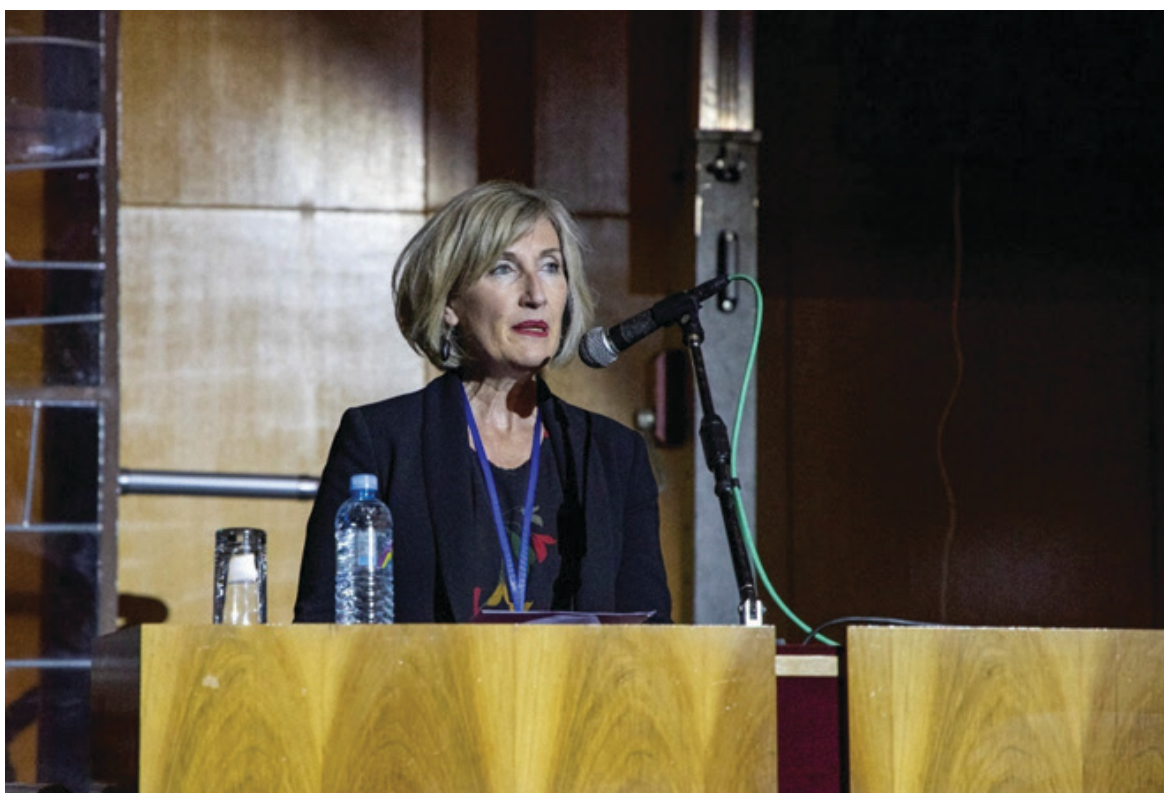


organs among the cities from the Balkans and with the international nephrology community. It was important to create opportunities for the exchange of expert experience and knowledge, and to take part in collaborative projects. The first BANTAO Congress was held in Varna, Bulgaria from 22 to 24 September 1995, and from that year the Congress had been held every two years, and from 2017 every year. Since 2005, the congresses have been followed by 9 CME courses supported by the ERA-EDTA and/or the ISN: 2005 - Ohrid (BANTAO), 2006 - Skopje (MSNDTAO), 2009 - Skopje (MSNDTAO), 2010 - Skopje (ERA-EDTA - ESAO), 2011 (ERA-EDTA \& EUTox group), 2012 - Ohrid (MSNDTAO), 2014 - Skopje (MSNDTAO), 2016 - Skopje (MSNDTAO), 2018 - Skopje (MSNDTAO - ERA-EDTA \& ISN), 2019 - Skopje (BANTAO - ISN \& ERA-EDTA). The congresses have succeeded in raising the nephrology knowledge and in increasing the standards of the nephrology patient care throughout the Balkans. In 2003, alongside this association, the first issue of the BANTAO journal was published, which has further enhanced the collaboration between the medical communities in this region.

The Macedonian Society of Nephrology, Dialysis, Transplantation and Artificial Organs (MSNDTAO) was created in 1992. The first Congress of the MSNDTAO was held on 9th Octo- ber 1993 and from that time the Society has been very active in education and in collaboration with BANTAO, the European Renal Association (ERA-EDTA) and the International Society of Nephrology (ISN). Since its creation MSNDTAO has had a history of very successful National Congresses, many sections and international meetings with nephrologists from the neighboring and the countries from the South East Europe, exchanging knowledge and updating the current information on specific topics. MSNDTAO is also an initiator of the foundation of BANTAO.

The 15th BANTAO and the 6th MSNDTAO Congress were highly professional events in honor of the 80th anniversary of Academician Prof. Dr. Momir Polenakovic from Republic of North Macedonia. Academician Polenakovic is one of the founders of BANTAO and MSNDTAO, who was unselfishly dedicated to education and guidance for many generations of young doctors in this region.

This year's Congress was endorsed by the ERA-EDTA (European Renal Association-European Dialysis and Transplant Association), and supported by the International Society of Nephrology (ISN). The ISN CME Course with ERA-EDTA endorsement that followed on Day 3 of this professional event raised great interest from the participants and the evaluation feedback was with the highest scores.

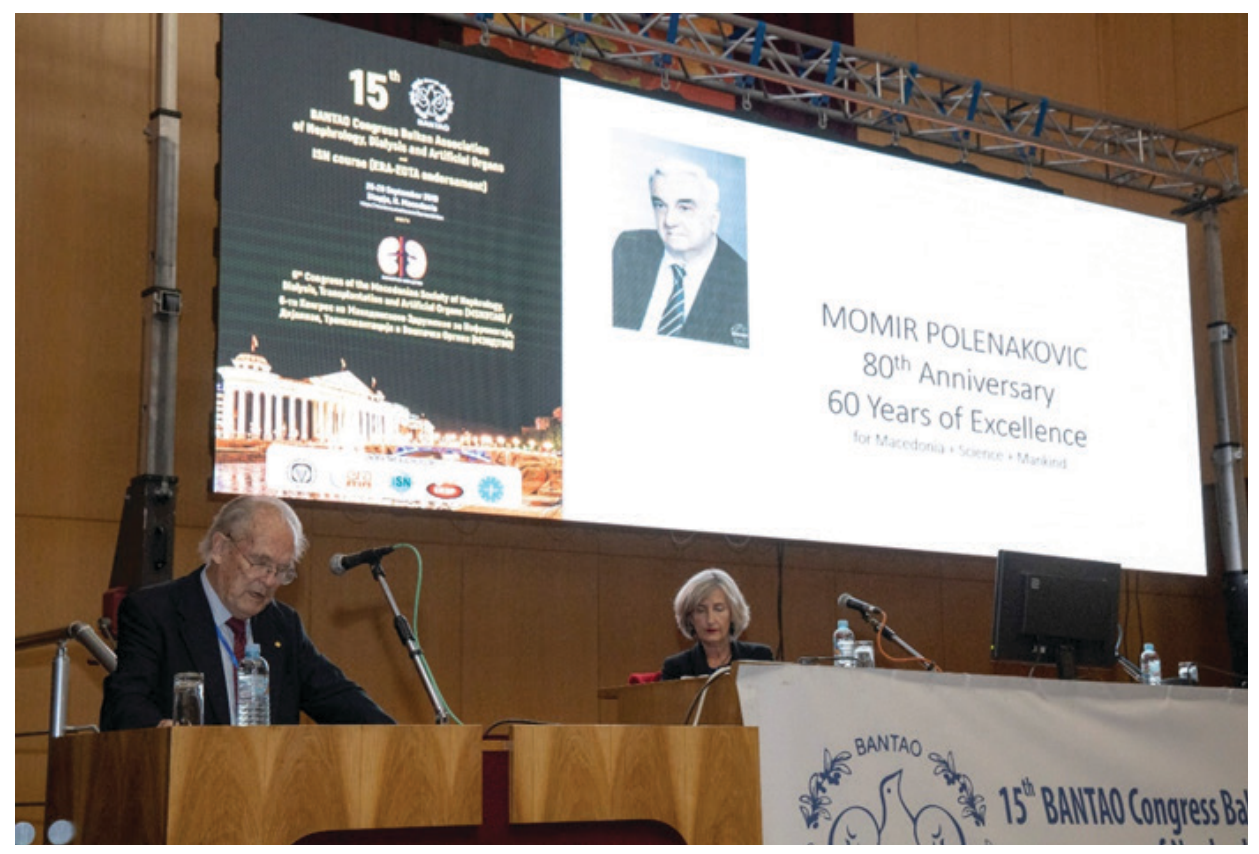

Fig. 25. Horst Klinkmann 
The Scientific Committee of the Congress paid great attention to various topics in the field of Nephrology and treatment of chronic renal disease. Around 250 participants (Nephrologist, Researchers, Medical and Other Trainees - Including residents, graduate students, post-docs, and fellows of the region, health care professionals interested in nephrology, dialysis, transplantation, and artificial organs) from 15 countries from the region and abroad attended the Congress. The main topics that were discussed, throughout state of the art presentations and mini lectures included Clinical Nephrology, Hypertension, Nephrolithiasis, Urinary tract infections, Adult dominant polycystic kidney disease, Prevention and treatment of Chronic Kidney Disease, and Renal Replacement Therapy (Hemodialysis, Peritoneal Dialysis, Kidney Transplantation). In depth knowledge exchange within dedicated sessions were the chapters on Vascular Accesses (creation, surveillance and management of complications, both medical and surgical), Immunosuppressive treatment in Clinical nephrology and Kidney transplantation, etc. The participants had an opportunity to listen 47 well known and distinguished international experts and scientists as invited speakers, from different parts of the Balkans and worldwide including Belgium, Czech Republic, Romania, Japan and United Kingdom. The four-day event also included 14 free communications, 56 e-poster presentations, and sponsored 3 mini symposiums. Review of active participants per engagement are shown in table 1.

\section{Daily report - DAY 1}

At the first day of the Congress, a European Renal Best Practice (ERBP) session was held in which the Chair of the ERBP Working Group, Prof. Dr. Jonathan Fox gave a comprehensive insight of the purpose and aims of ERBP, methods used for their achievement, and an overview of the recent and guidelines in development. He concluded that ERBP is the guidance body of ERA-EDTA; they want to be as transparent and unbiased as possible; they strive to achieve the highest standards of guideline/guidance development; their aim is to produce documents that are relevant to their stakeholders and useful in improving the outcomes for patients with kidney disease; and their willingness to welcome involvement of individuals and national societies of ERA-EDTA member countries. Dr. Evi Nagler, the Vice-chair of the Board of ERBP Working Group, talked about the latest guidelines (2019) for management of elderly patients with chronic kidney disease (CKD) and introduction of the latest clinical practice guidelines on peri- and postoperative care of arteriovenous fistulas and grafts for hemodialysis in adults.

Table 1. Engaged active participants per country

\begin{tabular}{|c|c|c|c|}
\hline Country & \# Invited lectures & $\begin{array}{c}\text { \# Free } \\
\text { communications }\end{array}$ & $\begin{array}{c}\text { \# Poster } \\
\text { presentations }\end{array}$ \\
\hline Albania & 4 & & 10 \\
\hline Belgium & 2 & & \\
\hline Germany & & 1 & \\
\hline Greece & 6 & 6 & 4 \\
\hline Croatia & 4 & 2 & 5 \\
\hline Czech Republic & 1 & & \\
\hline Bosnia and Herzegovina & 4 & 1 & 1 \\
\hline Romania & 2 & & 3 \\
\hline Japan & 1 & & \\
\hline Montenegro & 1 & & \\
\hline Serbia & 5 & 1 & 2 \\
\hline Slovenia & 2 & & 2 \\
\hline Turkey & 4 & & 4 \\
\hline $\mathrm{UK}$ & 2 & & \\
\hline N. Macedonia & 9 & 3 & 25 \\
\hline
\end{tabular}




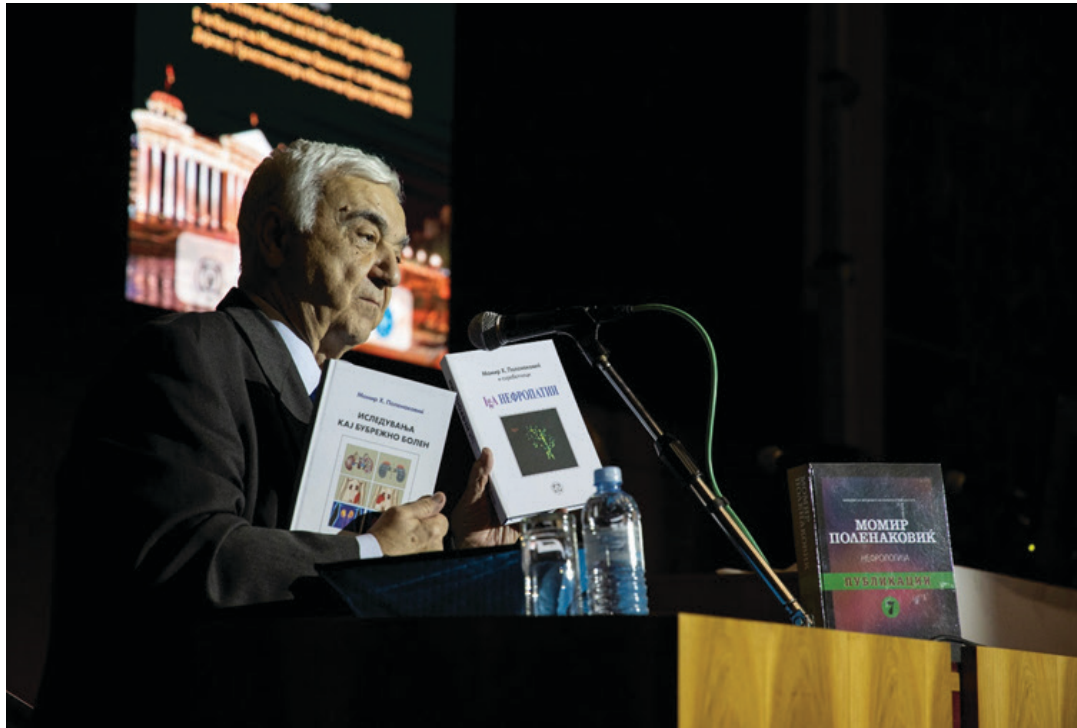

Fig. 26. Momir Polenakovic presented MSNDTAO with two books

Fig. 27. Goce Spasovski presented Momir Polenakovic with the BANTAO
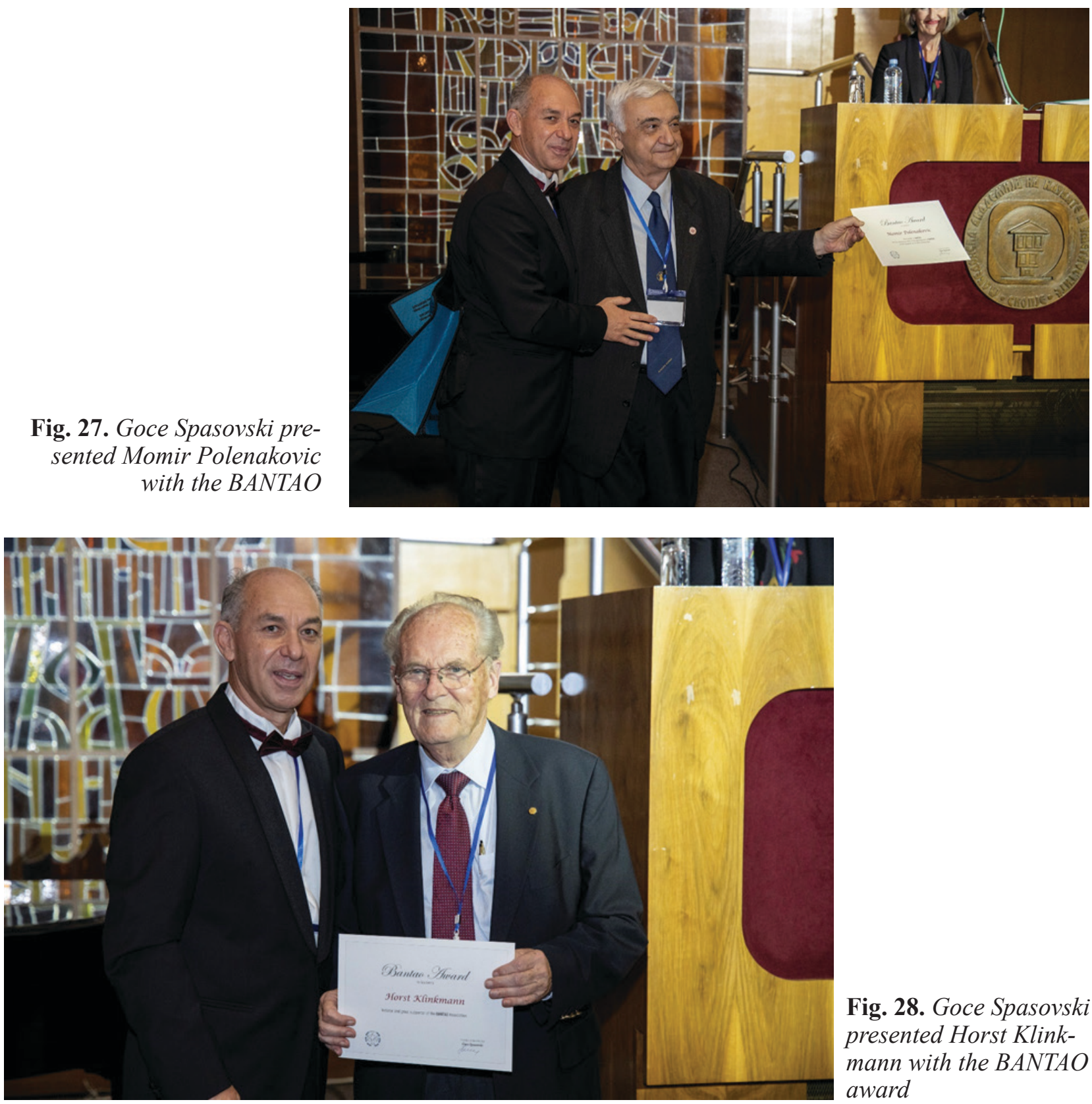

Fig. 28. Goce Spasovski presented Horst Klinkmann with the BANTAO award 


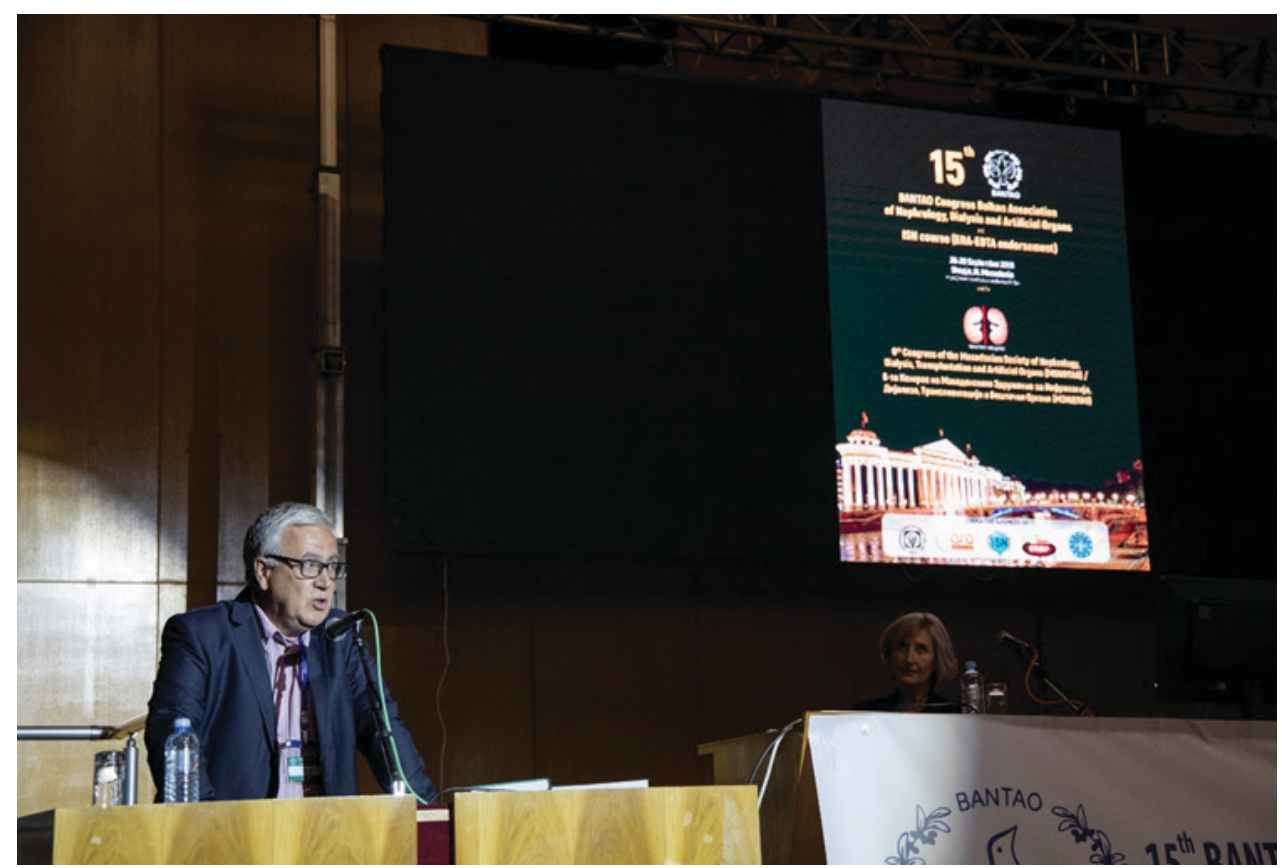

Fig. 29. Velibor Tasic,

Chair of the session

Fig. 30. ISN Pioneer Award
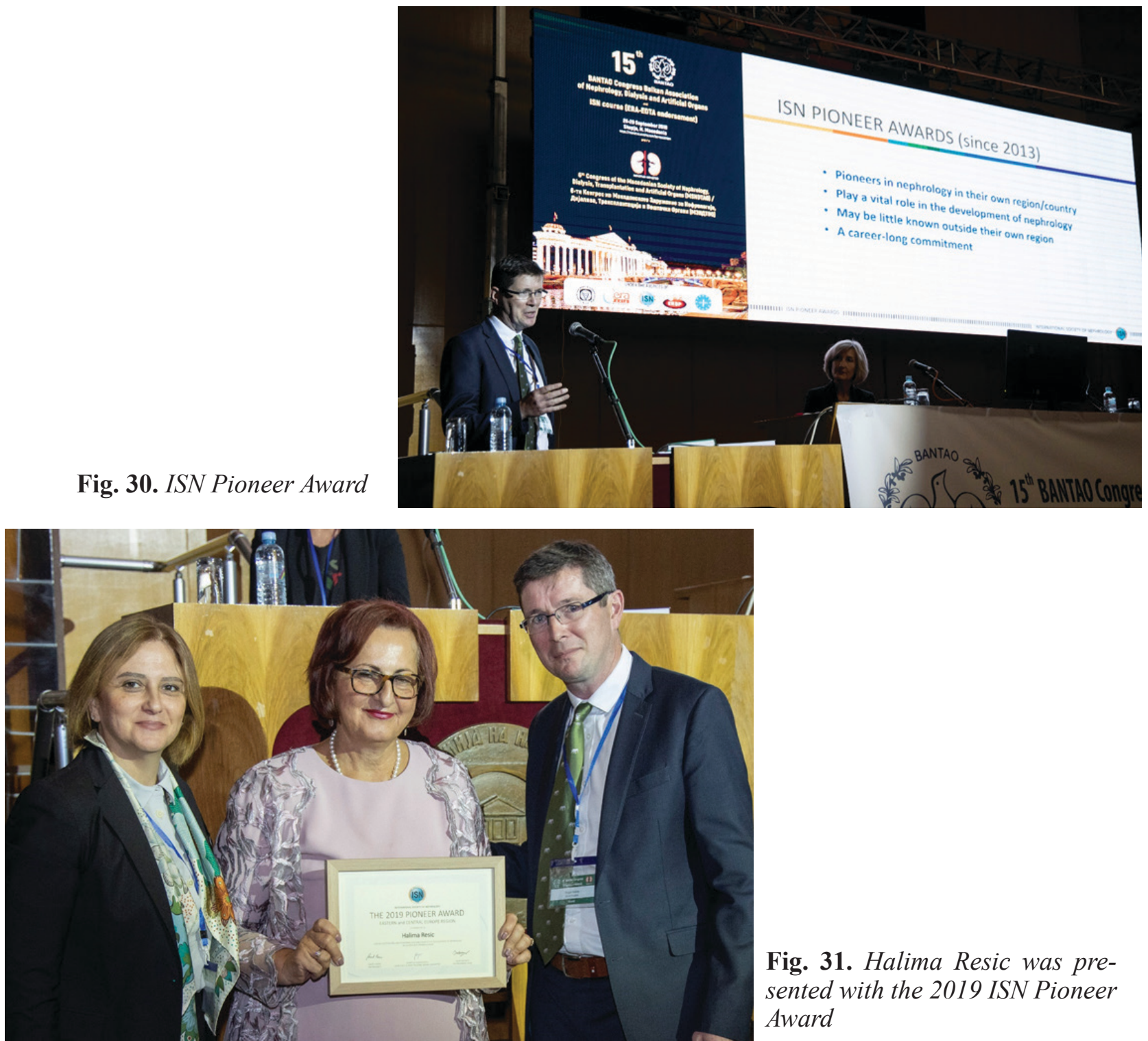

Fig. 31. Halima Resic was presented with the 2019 ISN Pioneer Award 
During the official welcoming ceremony, along presentation about the history and many achievements of the both Associations, BANTAO and MSNDTAO, a few awards of recognition were delivered. The current President of the BANTAO Society, Prof. Dr. Halima Resic from the University of Sarajevo, Bosnia and Herzegovina received the ISN Pioneering Award for the Eastern and Central European Region for 2019 from Fergus Caskey for her vital role in the development and career-long commitment in improving nephrology in this region.

Prof. Dr. Horst Klinkmann had a speech in honor of the 80th Anniversary and 60 years of Excellence of Academician Prof. Dr. Momir Polenakovic. He referred on his great scientific experience acquired in the work with kidney patients, and after the visit to the most renowned nephrology centers in Europe and the world, he has transferred it to his colleagues throughout their mutual work within the medical units and nephrology associations. The work of the Associations was in fact a successful education of around 1.000 students, post graduate and post docs colleagues. Among his most distinguished positions, apart from being a founder and President of the MSNDTAO, President of the Yugoslav Society of Nephrology, founder and President of BANTAO, are also, the member of the ESAO and ERA-EDTA Boards. Academician Polenakovic is author of around 480 original articles, editorials, reviews and chapters; several books and book chapters; 7 research projects with partners from abroad; 14 national research projects; 31 Honorary Memberships, Degrees, Presidency and plenty of other recognitions and awards for his work achievements.

Additionally, the President of the Congress, Prof. Dr. Goce Spasovski from Republic of North Macedonia, awarded three renowned international experts with the BANTAO award, Academician Prof. Dr. Momir Polenakovic, Prof. Dr. Horst Klinkmann and Prof. Dr. Raymond Vanholder, for their outstanding support of the Association and the whole region.

\section{Daily report - DAY 2}

The second day was organized in four sessions: Clinical nephrology and renal registries; CKD Diagnosis, comorbidities and treatment; Kidney transplantation and Acute and chronic renal failure management, where the renowned invited lecturers presented their lectures. Additionally, two sponsored mini symposiums were held, and the first 6 interesting free communications were presented.

\section{Daily report - DAY 3}

On the third congress day, the ISN CME Course with ERA-EDTA endorsement was held (Image 4 Participants carefully following the topics of the CME course). The course was entitled "Possibility of diagnosis and treatment of the CKD progression and complications/Possibility of diagnosis and treatment of the CKD progression - current perspective" and chaired by Caskey Fergus and Serhan Tuglular. The selection of the topic was based on the fact that CKD is associated with an increased risk for a variety of clinical comorbidities, so it would be an imperative to employ effective strategies to slow down the progression earlier in the course of the disease. Efforts to identify those who are at greater risk for disease progression are complicated by the myriad factors that may be involved. It is important to screen people with an early evidence of diabetes or hypertension as a rational strategy. Many knowledge gaps exist and an additional research is needed to improve our ability to adequately screen for, monitor, and/ or treat CKD. It is likely that newer treatment strategies employed may be helpful. Given that $11 \%$ of the adult population has an early evidence of CKD, and that it is associated with increased cardiovascular disease and mortality, a greater attention and focus is needed for tailoring optimal treatment strategies. The pediatric session was dedicated on renal replacement therapy and its complications. The third well-attended industry symposium provided an update on the most challenging problems and strategies for achieving the best outcomes in patients' treatment and their management.

\section{Daily report - DAY 4}

Finally, on the last day of the Congress, before the official closure and best wishes from the President of the Congress, a session about CKD and renal replacement therapy complications was held. The last 8 speakers presented in the second part of the free communication session.

\section{CONCLUSIONS}

This event was of an exceptional importance for the region, considering the charred international achievements and the most up-to- 
date methods used in the Nephrology field. The rich variety of speakers and activities provided fresh impetus for advancements in education as well. We are also confident, that we'll further proceed with our well established BANTAO spirit or even get stronger bonds among us all who share the common goal of improvement in the Nephrology sphere. Thus, we'll be able to propose to our health decision-makers the introduction of proven state of the art procedures in the prevention and treatment of kidney diseases that will further improve the quality of life of our patients. We have tried to provide learning opportunities from experts, but also we invited many colleagues from the region to actively participate in sharing their clinical experience and research. This meeting is expected to bring out continuous quality improvement in the treatment of patients with renal diseases being qualitatively valued with 20 CME points from UEMS accreditation services. [9]

Numerous participants from the Republic of Macedonia, the Balkans and the world participated in these six congresses.

Between the congresses, numerous local meetings of MSNDTAO have been held in the Republic of Macedonia, as well as meetings with the nephrological associations from Croatia, Serbia, Albania and Kosovo. These meetings stimulated the development of nephrology in the region and beyond.

\section{Acknowledgement to Goce Aleksoski for the technical assistance.}

The paper is part of the project "History of Nephrology in North Macedonia", funded by the Macedonian Academy of Sciences and Arts.

\section{REFERENCES}

1. First scientific meeting of the Yugoslav nephrologists with international participation, Struga, 26-28. IX 1977, Proceedings, Documenta 1977, Galenika, Beograd, 1977, 3-723.

2. Nephrology '89 (Proceedings of the IV. Congress of Yugoslav Nephrologists, Skopje, 27-30. IX 1989) Mac. Med. Review, 43, supp. 9, 1-519, 1989.

3. "Nephrology today and tomorrow". Scientific symposium dedicated to the anniversary: 20 years of chronic hemodialysis in Macedonia. Mac. Med. Review, sup. 12, 1-86, 1993.

4. M. Polenakovic, G. Spasovski: Ideas and spirit of the Balkan Cities Association of Nephrology, Dialysis, Transplantation and Artificial Organs (BANTAO) connect nephrologists from the Balkan cities - from the foundation to the 15th BANTAO Congress, Contributions (Prilozi) Sec. of Med. Sci. XL 3, 2019.

5. Nephrology '93. Proceedings of the First Congress of the Macedonian Society of Nephrology, Dialysis, Transplantation and Artificla Organs, Mac. Med. Review, 47, supp. 14, 1994, 5-407.

6. Proceedings of the 2nd Congress of the Balkan Cities Association of Nephrology, Dialysis, Transplantation and Artificial Organs (BANTAO), Struga, R. Macedonia, September 6-8, 1997. Mac. Med. Review, 57: sup. 35, 1-154, 1999.

7. Third Macedonian Congress of nephrology with international participation (Book of Abstracts). Mac. Med. Review, 55 (suppl. 48), 1-135, 2001.

8. G. Spasovski, M. Polenakovic. Fourth Congress of the Macedonian Society of Nephrology, Dialysis and Artificial Orgams (MSNDTAO), Ohrid, 2124 June 2012. Contributions (Prilozi) Sec. Biol. Med. Sci., MASA XXXIII 2, 283-284 (2012).

9. Nikolina Smokovska and Goce Spasovski. Congress report from highly scientific nephrology congresses in the Balkans, 15th BANTAO and 6th MSNDTAO congress. contributions. Sec. of Med. Sci., XL 3, 2019 


\title{
Резиме
}

\section{ШЕСТ КОНГРЕСИ НА МАКЕДОНСКОТО ЗДРУЖЕНИЕ ЗА НЕФРОЛОГИЈА, ДИЈАЛИЗА, ТРАНСПЛАНТАЦИЈА И ВЕШТАЧКИ ОРГАНИ (МЗНДТВО) - ПОТТИК ЗА РАЗВОЈ НА НЕФРОЛОГИЈАТА ВО С МАКЕДОНИЈА}

\author{
Момир Х. Поленаковиќ ${ }^{1}$ и Гоце Спасовски른 \\ ${ }^{1}$ Македонска академија на науките и уметностите, Скопје, РС Македонија \\ ${ }^{2}$ Клиника за нефрологија, Медицински факултет, Универзитет „Св. Кирил и Методиј“, Скопје, РС \\ Македонија
}

Македонското здружение за нефрологија, дијализа, трансплантација и вештачки органи (МЗНДТВО) е формирано на 1 септември 1992 година, со цел стимулирање на развојот на нефрологијата и обединување на експерти од сите струки заинтересирани за истражувањето и лекувањето на бубрежните болни. За претседател на МЗНДТВО беше избран Момир Х. Поленаковиќ.

Првиот конгрес на МЗНДТВО се одржа во Охрид од 7 до 10 октомври 1993 година во хотел „Десарет“, под покровителство на првиот претседател на Р Македонија, Киро Глигоров. Во текот на Конгресот беше формиран Balkan Cities Association of Nephrology, Dialysis, Transplantation and Artificial Organs (BANTAO) на 9 октомври 1993 година. Промовирана е и идејата за соработка со Клиниката за нефрологија од Универзитетот Еге, Измир, Р Турција. Дел од изнесените трудови беа отпечатени во Зборникот на трудови „Нефрологија '93““, како суплемент на Македонски медицински преглед. Беше промовирана и „Доктрина за изведување на нефролошка дејност во Република Македонија“.

Вториот конгрес на МЗНДТВО беше одржан во Струга, Р Македонија од 6 до 10 септември 1997 година, заедно со Вториот конгрес на БАНТАО. Одбрани трудови беа отпечатени во Македонски медицински преглед

Третиот конгрес на МЗНДТВО се одржа од 30 мај до 2 јуни 2001 година во Скопје, во Македонската академија на науките и уметностите (МАНУ). Беше отпечатен и зборник на трудови. Во 2011 година М. Х. Поленаковиќ беше избран за доживотен почесен претседател на МЗНДТВО, а за актуелен претседател на МЗНДТВО беше избран Гоце Спасовски.

Четвртиот конгрес на МЗНДТВО се одржа во Охрид од 21 до 24 јуни 2012 година, заедно со Fourth Meeting of the South-Eastern European Pediatric Nephrology Working Group (SEEPNWG).

Петтиот конгрес на МЗНДТВО се одржа од 9 до 12 јуни 2016 година во Скопје, во МАНУ, заедно со 6th Southeastern European Pediatric Nephrology Working Group (SEPNWG) Meeting and IPNA (International Pediatric Nephrology Association) Teaching Course. Во текот на Конгресот се одржаа и VIII македонско-хрватски нефролошки денови.

Шестиот конгрес на МЗНДТВО се одржа од 26 до 29 септември 2019 година заедно со 15. Конгрес на БАНТАО, во Скопје, во МАНУ. На Конгресот беше одбележена и 80 -годишнината од раѓањето на М. Х. Поленаковиќ.

На сите конгреси, покрај учесниците од Р Македонија, учествуваа и познати нефролози од Европа и од светот.

Новина на последните конгреси беше организирањето на 9 CME (континуирана медицинска едукација) курсеви со познати предавачи: CME courses supported by the ERA-EDTA and/or the ISN: 2005 - Ohrid (BANTAO), 2006 - Skopje (MSNDTAO), 2009 - Skopje (MSNDTAO), 2010 - Skopje (ERAEDTA - ESAO), 2011 Skopje (ERA-EDTA - EUTox group), 2012 - Ohrid (MSNDTAO), 2014 - Skopje (MSNDTAO), 2016 - Skopje (MSNDTAO), 2018 - Skopje (MSNDTAO - ERA-EDTA \& ISN), 2019-Skopje (BANTAO - ISN \& ERA-EDTA).

Освен конгресите, МЗНДТВО имаше одржано состаноци и со нефролошките здруженија од Хрватска, Србија, Албанија и од Косово.

Конгресите на МЗНДТВО придонесоа за запознавањето и едукацијата на лекарите во дијагностицирањето и лекувањето на бубрежните болни. Тие беа силна стимулирале за развојот на нефрологијата во Р Македонија и пошироко.

Клучни зборови: Македонското здружение за нефрологија, дијализа, трансплантација и вештачки органи (МЗНДТВО), конгреси, СМЕ (континуирана медицинска едукација) 